\title{
ANALISIS PRODUK DOMESTIK REGIONAL BRUTO, INFLASI DAN NET EKSPOR PROVINSI DI INDONESIA
}

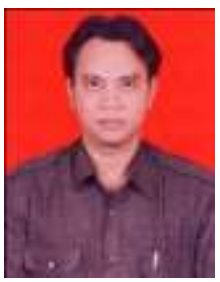

Oleh:

\author{
Aris Munandar, SE., M.Si
}

Tujuan dari penelitian ini adalah untuk menganalisis produk domestik bruto, inflasi dan bersih ekspor daerah provinsi di Indonesia. Penulisan Ini termotivasi oleh kecenderungan melambatnya pertumbuhan ekonomi, kenaikan inflasi dan penurunan ekspor bersih dalam penelitian Indonesia. Menggunakan data panel dari 33 provinsi di Indonesia pada periode 2009-2013. Data dianalisis dengan menggunakan regresi, metode Ordinary Least Squares (OLS), melalui perangkat lunak statistik.

Hasil Penelitian pertama menunjukkan bahwa variasi 99,8\% dalam produk domestik regional bruto dapat dijelaskan oleh variasi dalam belanja pemerintah, investasi asing, investasi domestik, dan ekspor neto. Variabel independen secara simultan memiliki pengaruh yang signifikan terhadap PDRB. investasi asing sebagian kontribusi lebih dari variabel lain, peningkatan i.e.an investasi asing sebesar 1\% akan meningkatkan PDRB sebesar 34\%.

Kedua menunjukkan bahwa variasi $88,6 \%$ di ekspor bersih dapat dijelaskan oleh variasi dalam rupiah Indonesia untuk tukar mata uang asing dolar AS dan pertumbuhan ekonomi dunia. Variabel independen secara simultan memiliki pengaruh yang signifikan terhadap ekspor neto. nilai tukar rupiah Indonesia sebagian memiliki efek yang signifikan negatif pada ekspor bersih, sedangkan pertumbuhan ekonomi dunia memiliki dampak positif yang signifikan pada ekspor neto.

Ketiga menunjukkan bahwa variasi 36,2\% inflasi dapat dijelaskan variasi dalam konsumsi rumah tangga dan impor. Variabel independen secara simultan memiliki pengaruh yang signifikan terhadap inflasi. Variabel impor sebagian tidak berpengaruh signifikan terhadap inflasi.

Kata kunci: Pertumbuhan Ekonomi, PDRB, FDI dan investasi domestik, net exports, inflasi, pengeluaran pemerintah

\section{PENDAHULUAN}

Pada dasarnya, pertumbuhan ekonomi diartikan sebagai suatu proses pertumbuhan output perkapita dalam jangka panjang. Hal ini berarti, bahwa dalam jangka panjang kesejahteraan tercermin pada peningkatan output perkapita yang sekaligus memberikan banyak alternatif dalam mengkonsumsi barang dan jasa, serta diikuti oleh daya beli masyarakat yang semangkin meningkat. Pertumbuhan ekonomi jugabersangkut paut dengan proses peningkatan produksi barang dan jasa dalam kegiatan ekonomi masyarakat. Sehingga dapat dikatakan bahwa pertumbuhan ekonomi menyangkut perkembangan yang berdimensi tunggal dan diukur dengan meningkatnya hasil produksi dan pendapatan. (Boediono,2005).

Selama periode tahun 2009 - 2013, pertumbuhan ekonomi Indonesia tertinggi terjadi pada tahun 2011 sebesar 6,49\%. Kenaikan pertumbuhan ekonomi pada tahun ini diduga diakibatkan oleh pengaruh dari faktor - faktor yang mempengaruhinya 
diantaranya adalah peningkatan konsumsi, investasi dan pengeluaran pemerintah. Disamping itu, pertumbuhan ekonomi Indonesia terendah terjadi pada tahun 2009 sebesar $5,00 \%$. Rendahnya pertumbuhan ekonomi Indonesia pada tahun ini diduga disebabkan oleh turunnya konsumsi, investasi, pengeluaran pemerintah (Badan Pusat Statistik, 2013).

Krisis ekonomi global yang melanda sebagian besar negara di dunia termasuk Indonesia, memperlihatkan bahwa keseimbangan dalam perekonomian suatu negara tidak bisa dengan hanya mengandalkan sektor swasta. Kontribusi sektor pemerintah juga sangat dihandalkan. Terutama faktor pengeluaran pemerintah, investasi pemerintah yang dapat menciptakan lapangan pekerjaan dan net ekspor yang dapat meningkatkan pendapatan nasional.

Untuk mendorong pertumbuhan ekonomi maka Pemerintah juga akan melakukan peningkatan pengeluarannya. Pengeluaran pemerintah mencerminkan kebijakan pemerintah. Apabila pemerintah telah menetapkan suatu kebijakan untuk membeli barang dan jasa, penegeluaran pemerintah mencerminkan biaya yang harus dikeluarkan oleh pemerintah untuk melaksanakan kebijakan tersebut.

Pada tahap awal perkembangan ekonomi diperlukan pengeluaran negara yang besar untuk investasi pemerintah, utamanya untuk menyediakan infrastruktur seperti sarana jalan, kesehatan dan pendidikan. Pada tahap menengah pembangunan ekonomi, investasi tetap diperlukan untuk pertumbuhan ekonomi, namun diharapkan investasi sektor swasta sudah mulai berkembang. Pada tahap lanjut pembangunan ekonomi, pengeluaran pemerintah tetap diperlukan, utamanya untuk meningkatkan kesejahteraan masyarakat, misalnya peningkatan pendidikan, kesehatan dan jaminan sosial.

Perekonomian suatu Negara juga tidak dapat berdiri sendiri tetapi berhubungan dengan kerjasama dengan Negara lain. Terjadinya pergeseran siklus dan tatanan ekonomi global merupakan tantangan yang dihadapi perekonomian global. Tantangan tersebut tidaklah ringan, mengingat pergeseran siklus terjadi di tiga area berbeda yang saling terkait satu sama lain. Pergeseran pertama ialah beralihnya lanskap ekonomi dunia yang ditandai oleh meningkatnya pertumbuhan ekonomi negara maju dan menurunnya pertumbuhan ekonomi negara berkembang. Pergeseran kedua terkait dengan berlanjutnya tren penurunan harga komoditas dunia. Pergeseran yang terakhir adalah mulai beralihnya arus modal dunia, dipengaruhi berakhirnya era kebijakan moneter longgar di AS. (Bank Indonesia. 2013).

Kondisi perekonomian global yang masih mengalami tekanan akibat krisis menghadapkan perekonomian Indonesia pada sejumlah tantangan yang tidak ringan selama tahun 2009. Tantangan itu cukup mengemuka pada awal tahun 2009, sebagai akibat masih kuatnya dampak krisis perekonomian global yang mencapai puncaknya pada triwulan IV 2008. Ketidakpastian yang terkait dengan sampai seberapa dalam kontraksi global dan sampai seberapa cepat pemulihan ekonomi global akan terjadi, bukan saja menyebabkan tingginya risiko di sektor keuangan, tetapi juga berdampak negatif pada kegiatan ekonomi di sektor riil domestik. Kondisi tersebut mengakibatkan stabilitas moneter dan sistem keuangan pada triwulan I 2009 masih mengalami tekanan berat, sementara pertumbuhan ekonomi juga dalam tren menurun akibat kontraksi ekspor barang dan jasa yang cukup dalam. Kondisi tersebut 
menurunkan kepercayaan pelaku ekonomi di sektor keuangan dan sektor riil, serta berpotensi menurunkan berbagai kinerja positif yang telah dicapai dalam beberapa tahun sebelumnya. (Badan Pusat Statistik, 2014)

Sehubungan dengan hal diatas, maka perlu dilakukan suatu pengkajian ilmiah terhadap faktor - faktor yang mempengaruhi Produk Domestik Regional Bruto, Inflasi dan net ekspor provinsi di Indonesia. Dalam hal ini faktor - faktor yang dianalisis adalah Ekspor dan impor, Pengeluaran Pemerintah, Konsumsi Rumah Tangga dan Investasi.

\section{STUDI KEPUSTAKAAN}

\section{Pengertian Pertumbuhan Ekonomi}

Secara umum, pertumbuhan ekonomi didefenisikan sebagai peningkatan kemampuan dari suatu perekonomian dalam memproduksi barang-barang dan jasa-jasa. Pertumbuhan ekonomi adalah salah satu indikator yang amat penting dalam melakukan analisis tentang pembangunan ekonomi yang terjadi pada suatu negara. Pertumbuhan ekonomi menunjukkan sejauh mana aktivitas perekomian akan menghasilkan tambahan pendapatan masyarakat pada suatu periode tertentu. Karena pada dasarnya aktivitas perekonomian adalah suatu proses penggunaan faktor - faktor produksi untuk menghasilkan output, maka proses ini pada gilirannya akan menghasilkan suatu aliran balas jasa terhadap faktor produksi yang dimiliki oleh masyarakat. Dengan adanya pertumbuhan ekonomi maka diharapkan pendapatan masyarakat sebagai pemilik faktor produksi juga akan meningkat.

Pertumbuhan ekonomi bisa bersumber dari pertumbuhan pada sisi permintaan agregat dan sisi penawaran agregat. Seperti yang diilustrasikan pada gambar 1, titik perpotongan antara kurva permintaan agregat dan kurva penawaran agregat adalah titik keseimbangan ekonomi (equilibrium) yang menghasilkan suatu jumlah output agregat (PDB) tertentu dengan tingkat harga umum tertentu. Output agregat yang dihasilkan selanjutnya membentuk pendapatan nasional.

Teori - teori pertumbuhan ekonomi yang berkembang antara lain:

1. Teori Pertumbuhan Klasik

2. TeoriPertumbuhanHarrod-Domar

3. TeoriPertumbuhanEkonomiSolow-Swan

\section{Teori Pengeluaran Pemerintah}

Teorimikro mengenai pengeluaran pemerintah menyangkut faktor- faktor yang mempengaruhi timbulnya permintaan akan barang - barang publik dan faktor - faktor yang mempengaruhi tersedianya barang publik. Interaksi antara permintaan dan penawaran barang publik menentukan jumlah barang publik yang disediakan yang selanjutnya akan menimbulkan permintaan terhadap barang lain. Beberapa faktor yang mempengaruhi pengeluaran pemerintah yaitu:

a. Perubahan permintaan akan barang publik.

b. Perubahan dari aktivitas pemerintah dalam menghasilkan barang publik dan perubahan dari kombinasi faktor produksi yang digunakan.

c. Perubahan kualitas barang publik.

d. Perubahan harga faktor-faktor produksi.

\section{Teori Konsumsi dari John Maynard Keynes}

Keynes mengedepankan variabel utama dalam analisisnya yaitu konsumsi dipengaruhi oleh tingkat pendapatan $\mathrm{C}=\mathrm{f}$ (Y). Keynes mengajukan 3 asumsi pokok secara makro dalamt eorinya yaitu:

1) Kecenderungan mengkonsumsi marginal (marginal propensity toconsume) ialah 
jumlah yang dikonsumsi dalam setiap tambahan pendapatan adalah antaranol dan satu.

2) Keynes menyatakan bahwa kecenderungan mengkonsumsi rata-rata (average prospensity toconsume), turunketika pendapatan naik.

3) Keynes berpendapat bahwa pendapatan merupakan determinan konsumsi yang penting dan tingkat bunga tidak memiliki peranan penting.

Sehingga secara garis besar terori konsumsi Keynes menyatakan bahwa, (besarkecil) konsumsi masyarakat sangat dipengaruhi oleh besarnya pendapatan. Sedangkan unsur tabungan tidak terlalu berdampak terhadap perubahan jumlah barang dan jasa yang dikonsumsi masyarakat.

\section{Teori Konsumsi dengan Hipotesis Pendapatan Permanen (Milton Friedman)}

Teori ini disampaikan oleh Milton Friedman tahun 1957. Menurut teori ini pendapatan masyarakat dapat diklasifikasikan menjadi 2 yaitu pendapatan permanen (permanentincome) dan pendapatan sementara (transitory income) dengan definisi sebagai berikut:

1) Pendapatan permanen ialah pendapatan yang orang harapkan untuk terus bertahan dimasa depan (Mankiw, 2000).

2) Pendapatan sementara ialah pendapatan yang tidak bisa diperkirakan sebelumnya. (Guritno dan Algifari, 1998).

Kesimpulannya, teori konsumsi dari Milton Friedman berpikiran bahwa pendapatan permanen akan mempengaruhi besarnya jumlah kecenderungan mengkonsumsi rata - rata masyarakat. Kecederungan mengkonsumsi tersebut bisa saja mengarah pada jenis makanan atau non makanan bergantung pada besar-kecilnya jumlah pendapatan yang diterima oleh masyarakat.

\section{Teori Konsumsi dengan Hipotesis Daur/Siklus Hidup}

Teori konsumsi dengan Hipotesis Siklus Hidup disampaikan dikemukaanoleh Franco Modigliani. Modigliani menyatakan bahwa faktor sosial ekonomi seseorang sangat mempengaruhi pola konsumsi seseorang tersebu (Guritnodan Algifari, 1998).

Modigliani menekankan bahwa pendapatan bervariasi dan tabungan secara sistematis yang terjadi selama kehidupan seseorang menjadi kankonsumen mampu menggerakkan pendapatannya ketika dalam kondisi tinggi ke kondisi yang rendah (Mankiw, 2007).

Sehingga teori konsumsi dengan Hipotesis Daur Hidup dari Franco Modigliani berkesimpulan bahwa, konsumsi seseorang sangat dipengaruhi oleh kekayaan atau besarnya pendapatan yang diperoleh. Kecenderungan mengkonsumsi nilainya berdasarkan pada umur, selera dan tingkat bunga yang dimiliki oleh konsumen itu sendiri.

\section{Teori Inflasi}

Tingkat harga dalam definisi inflasi, secara konseptual adalah tingkat harga ratarata tertimbang dari barang-barang dan jasajasa dalam perekonomian. Dalam prakteknya, tingkat harga tersebut diukur dengan indek harga, baik indek harga konsumen (IHK) mau pun indek harga produsen (IHP). Lawan dari inflasi adalah deflasi, yaitu penurunan tingkat harga umum (Samuelson dan Nordhaus, 1997:306)

Menurut Boediono (1994:155) definisi singkat dari inflasi adalah kecenderungan dari harga-harga untuk menaik secara umum dan terus menerus. Kenaikan harga dari satu atau dua barang saja tidak disebut inflasi. Syarat adanya kecenderungan menaikyang terus menerus juga perlu digaris - bawahi. 
Kenaikan harga-harga karena, misalnya, musiman, menjelang hariraya, bencana, dan sebagainya, yang sifatnya hanya sementara tidak disebut inflasi.

Jenis - jenis inflasi dapat dikelompokkan berdasarkan "parah-tidaknya" inflasi dan berdasarkan penyebab awal terjadinya inflasi.

Berdasarkan "parah-tidaknya", inflasi dapat dikelompokkan menjadi (Boediono, 1994:156):

1. Inflasi ringan (dibawah $10 \%$ setahun)

2. Inflasi sedang (antara10 $-30 \%$ setahun)

3. Inflasi berat (antara 30-100\% setahun)

4. Hiperinflasi (di atas $100 \%$ setahun).

Dalam hal ini Samuelson dan Nordhaus (1997:793), mengelompokkan inflasi menjadi tiga jenis, yaitu: inflasi moderat (moderat inflation), inflasi ganas (galloping inflation), dan hiperinflasi.

Berdasarkan penyebab awal terjadinya inflasi, inflasi dapat dikelompokkan menjadi (Boediono, 1994:156)

1. Inflasi yang timbul karena permintaan masyarakat akan berbagai barang terlalu kuat. Inflasi semacam ini disebut demand pullinflation.

2. Inflasi yang timbul karena kenaikan biaya produksi. Ini disebut cost pushinflation.

Kedua jenis inflasi ini jarang sekali dijumpai dalam praktek dalam bentuk yang murni. Pada umumnya, inflasi yang terjadi diberbagai negara di dunia adalah kombinasi dari kedua jenis inflasi tersebut, dan sering kali keduanya saling memperkuat satu sama lain.

\section{Teori Perdagangan Internasional}

Dalam perekonomian terbuka, terdapat terdapat dua tingkat harga umum yaitu harga umum yang berlaku didalam negeri dan tingkat harga yang berlaku diluar negeri. Pengaruh dari adanya harga luar negeri ini terhadap proses ekonomi makro khususnya terletak pada timbulnya kemungkinan bagi pelaku-pelaku ekonomi untuk memilih apakah mereka akan membeli atau menjual dipasar luar negeri atau pasar dalam negeri. Keputusan semacam ini jelas mempunyai pengaruh yang penting terhadap posisi keseimbangan pasar barang dalam negeri dan pasar uang dalam negeri. Secara umum bisa dikatakan bahwa bila harga dipasar dalam negeri meningkat lebih cepat dari pada harga diluar negeri, maka pembeli dalam negeri akan cenderung untuk membeli dari pasar luar negeri (jadi impor cenderumg meningkat) sedangkan para penjual dalam negeri akan cenderung untuk menjual barangnya dipasar dalam negeri yang menyebabkan ekspor ke luar negeri berkurang (Boediono, 2001).

Dengan mengunakan asumsi tersebut diperoleh kesimpulan bahwa dengan fungsi produksi yang sama dan bawaan faktor yang berbeda antar negara. Suatu negara cenderung untuk mengekspor komoditas yang relatif intensif dalam mengunakan fungsi yang relatif banyak dimiliki, dan dalam waktu yang bersamaan negara tersebut akan mengimpor komoditas yang produktifnya memerlukan sumberdaya yang relatif langka dan mahal (Salvatore, 1997).

Adanya unsur keterbatasan atau perbedaan ketersediaan sumber daya yang dimiliki setiap negara, merupakan faktor utama dari munculnya spesialisasi. prinsip ini merupakandasar berkembangnya ekonomi perdagangan dan keuangan internasional. Kondisi tersebut menggiring setiap negara melakukan ekspor dan impor. Ekspor adalah suatu kegiatan ekonomi menjual produk dalam negeri ke pasar luar negeri. Impor adalah suatu kegiatan membeli produk luar negeri untuk keperluan atau di pasarkan dalam negeri. Ekspor dan Impor sangat penting untuk membentuk dan mengendalikan neraca perdagangan disuatu negara. Impor harus dibiayai dengan nilai 
yang sama dari ekspor untuk mempertahankan ekuilibrium neraca perdagangan. Oleh karena itu negara harus melakukan ekporuntuk membiayai impor yang dibayarkan dengan mata uang asing sehingga dapat terjadi surplus neraca perdagangan.

Kegiatan ekspor-impor yang dilakukan suatu negara dengan negara lain dalam perdagangan internasional akan memberikan manfaat bagi suatu negara. kelangsungan ekspor dilatarbelakangi oleh excess supply oleh satu pihak dan excessdemand dipihaklain. Konsep excesssupply terjadi disebabkan kecenderungan tingkat harga suatu barang mengalami kenaikan di atas harga keseimbangan yang berlaku dipasar, baik pasar domestik maupunin ternasional. Sedangkan excessdemand justru sebaliknya yaitu kecenderungan tingkat harga dibawah harga keseimbangan. Besarnya ekspor suatu negara bergantung terhadap permintaan impor negara lain sehingga mencapai keseimbangan perdagangan internasional yang disebut balancedof international trade. (Nasution, 2008).

\section{Teori Investasi}

Investasidalam ekonomimakro, juga dapat dibedakan atas investasi otonom (otonomous investment) dan investasi terpengaruh (induced investment). Investasi otonom adalah investasi yang tidak dipengaruhi oleh pendapatan nasional, artinya tinggi rendahnya pendapatan nasional tidak menentukan jumlah investasi yang dilakukan oleh perusahaan-perusahaan. Jenis investasi ini umumnya dilakukan oleh pemerintah dengan maksud sebagai landasan pertumbuhan ekonomi berikutnya, misalnya investasi untuk pembuatanjalan, jembatan dan infrastruktur lainnya.

Sedangkan investasi yang terpengaruh adalah investasi yang dipengaruhi oleh pendapatan nasional, artinya pendapatan nasional yang tinggiakan memperbesar pendapatan masyarakat dan selanjutnya pendapatan masyarakat yang tinggi tersebut akan memperbesar permintaan terhadap barang-barang dan jasa-jasa. Maka keuntungan perusahaan akan bertambah tinggi dan ini akan mendorong dilakukannya lebih banyak investasi.

\section{Kurs Rupiah}

Nilai tukar mata uang (exchangerate) atau sering disebutkurs merupakan harga mata uang terhadap mata uang lainnya. Kurs mata uang adalah perbandingan nilai antar mata uang yang menunjukkan harga suatu mata uang jika dibandingkan dengan mata uang lain. Menurut Kuncoro (1997), ada beberapa sistem kurs mata uang yang berlaku di perekonomian internasional, yaitu:

a. Sistem kurs mengambang (floating exchangerate)

Sistem kurs ini ditentukan oleh mekanisme pasar dengan atau tanpa upaya stabilisas ioleh otoritas moneter. Dimana dalam sistem mengambang terdapat dua sistem yaitu sistem mengambang bebasdan sistem mengambang yang terkendali.

b. Sistem kurs tertambat (peggedex changerate).

Dalam sistem ini, suatu negara mengkaitkan nilai tukar mata uangnya dengan suatu mata uang negara lain atau sekelompok mata uang, yang biasanya merupakan mata uang negara partner dagang yang utama "menambatkan" kesuatu mata uang berarti nilai tukar mata uang tersebut bergerak mengikuti mata uang yangmenjadi tambatannya. Jadi sebenarnya mata uang yang ditambatkan tidak mengalami fluktuasi tetapihanya berfluktuasi terhadap mata uang lain mengikuti mata uang yang 
menjadi tambatannya.

c. Sistem kurs tertambat merangkak (crawlingpegs).

Dalam sistem ini, suatu negara melakukan sedikit perubahan dalam nilai tukar mata uangnya secara periodik dengan tujuan untuk bergerak menuju nilai tertentu pada rentang waktu tertentu. Keuntungan utama sistem ini adalah suatu negara dapat mengatur penyesuaian kursnya dalam periode yang lebih lama dibanding sistem kurs tertambat. Oleh karena itu, sistem ini dapat menghindar ikejutan- kejutan terhadap perekonomian akibat revaluasi atau devaluasi yang tiba-tiba dan tajam.

d. Sistem sekeranjang mata uang(basket of currencies).

Banyak negara terutama negara sedang berkemban menetapkan nilai tukar mata uangnya berdasarkan sekeranjang mata uang. Keuntungan dari sistem ini adalah menawarkan stabilitas mata uang suatu Negara karena pergerakan mata uang disebar dalam sekeranjang mata uang. Seleksi mata uang yang dimasukkan dalam "keranjang" umumnya ditentukan oleh peranannya dalam membiayai perdagangan Negara tertentu. Mata uang yang berlainan diberi bobot yang berbeda tergantung peran relatifnya terhadap negara tersebut. Jadi sekeranjang mata uang bagi suatu negara dapat terdiri dari beberapa mata uang yang berbeda dengan bobot yang berbeda.

e. Sistem kurs tetap (fixedex changerate).

Dalam sistem ini, suatu negara mengumumkan suatu kurs tertentu atas nama uangnya dan menjaga kurs ini dengan menyetujui untuk menjual atau membeli valas dalam jumlah tidak terbatas pada kurs tersebut. Kurs biasanya tetap atau diperbolehkan berfluktuasi dalam batas yang sangat sempit.

Dalam sistem mata uang mengambang bebas (free float), apa bila harga suatu mata uang menjadi semakin mahal terhadap mata uang lain, maka mata uang itu disebut berapresiasi. Sebaliknya jika harga suatu mata uang turun terhadap mata uang lain, mata uang itu disebut terdepresiasi.

Kurs mata uang asing mengalami perubahan nilai yang terus menerus dan relatif tidak stabil. Perubahan nilai ini dapat terjadi karena adanya perubahan permintaan dan penawaran atas suatu nilai mata uang asing pada masing-masing pasar pertukaran valuta dari waktu ke waktu. Sedangkan perubahan permintaan dan penawaran itu sendiri di pengaruhi oleh adanya kenaikan relatif tingkat bunga baik secara bersamasama maupun sendiri-sendiri terhadap negara.

\section{Penelitian Terdahulu}

Hasil penelitian I Made Yudisthira dan I Gede Sujana Budhiasa (2012) yang berjudul : Analisis Pengaruh Konsumsi, Investasi, dan Inflasi Terhadap Produk Domestik Bruto di Indonesia Tahun 20002012 menunjukkan bahwa Variabel konsumsi dan investasi berpengaruh positif dan signifikan terhadap Produk Domestik Bruto (PDB), sedangkan variabel inflasi berpengaruh positif namun tidak signifikan terhadap Produk Domestik Bruto (PDB). Besarnya R-squared pada hasil estimasi model PDB adalah sebesar 0.986631, yang berarti bahwa 98.6631 persen perubahan nilai PDB di Indonesia secara bersama-sama mampu dijelaskan oleh variabel independen yang digunakan dalam model, yaitu investasi, konsumsi, dan tingkat inflasi. Sedangkan sisanya sebesar 1.3369 persen dapat dijelaskan oleh variabel lain yang tidak dimasukkan ke dalam model, seperti tingkat 
ekspor, pengeluaran pemerintah,dan lainlain.

Adrian Sutawijaya dan Zulfahmi (2012) meneliti dengan judul: Pengaruh Faktor-Faktor Ekonomi Terhadap Inflasi di Indonesia, hasil penelitian menunjukkan bahwa tingkat suku bunga, jumlahuang beredar, investasi, dan nilai tukar secara simultan mempengaruhi inflasi di Indonesia. Tingkat bunga memiliki pengaruh positif 1,289\%. Uang beredar akan memiliki pengaruh positif terhadap inflasi $0,001 \%$. Investasi berdampak negatif inflasi ,0001802\%. Kurs memiliki dampak positif pada inflasi 0,00427\%.

Sri Endang Rahayu (2011) meneliti dengan judul: Analisis Pengaruh Pengeluaran Pemerintah Terhadap Pertumbuhan Ekonomi di Sumatera Utara, hasil penelitian menunjukkan pengeluaran aparatur daerah mempunyai pengaruh positif terhadap pertumbuhan ekonomi di Sumatera Utara dengan besar koefisien 35,697. Artinya apabila pengeluaran aparatur daerah naik $1 \%$, ceteris paribus maka pertumbuhan ekonomi di Sumatera Utara naik sebesar 35,697\%. Variabel $\mathrm{X}_{2}$ (pelayanan publik) mempunyai pengaruh positif terhadap pertumbuhan ekonomi diSumatera Utara dengan besar koefisien 51,062. Artinya apabila pelayanan publik naik $1 \%$, ceterisparibus maka pertumbuhan ekonomi di Sumatera Utara naik sebesar $51,062 \%$.

Primawan Wisda Nugroho, Maruto Umar Basuki (2012) meneliti dengan judul: Analisis Faktor Faktor Yang Mempengaruhi Inflasi Di Indonesia Periode 2000.1-2011.4, hasil penelitian menunjukkan Variabel produk domestik bruto (PDB) memiliki hubungan positif dan signifikan terhadap inflasi dengan nilai koefisien sebesar 0,011, artinya apabila variable independen lainnya konstan, maka setiap kenaikan PDB sebesar satu rupiah akan menaikkan inflasi sebesar 0,011. Variabel suku bunga Sertifikat Bank Indonesia (SBI), memiliki hubungan positifdan signifikan terhadap inflasi dengan nilai koefisien sebesar 1,08, artinya apabila variabel independen lainnya konstan, maka setiap kenaikan SBI sebesar satu rupiah akan menaikkan inflasi sebesar 1,08.Variabel jumlah uang beredar dalam arti luas (M2) memiliki hubungan negatif dan signifikan terhadap inflasi dengan nilai koefisien sebesar 0,001, artinya apabila variabel independen lainnya konstan, maka setiap kenaikan jumlah uang beredar (M2) sebesar satu rupiah akan menurunkan Inflasi sebesar 0,001.Variabelkurs memiliki hubungan positif dan tidak signifikan terhadap inflasi dengan nilai koefisien sebesar 0.001, artinya apabila variabel independen lainnya konstan, maka setiap kenaikan tingkat kurs sebesar saturupiah akan menaikkan Inflasi sebesar 0.001 .

Sev EkaPutra, SyamsulAmar dan Efrizal Syofyan (2013) meneliti dengan judul: Analisis Faktor Faktor Yang Mempengaruhi Net Ekspor dan Pertumbuhan Ekonomi Di Provinsi Jambi, hasil penelitian menunjukkan Konsumsi, investasi, pengeluaran pemerintah dan net ekspor berpengaruh signifikan terhadap pertumbuhan ekonomi. Sementara itu, secara parsial konsumsi berpengaruh signifikan dan positif terhadap pertumbuhan ekonomi. Investasi berpengaruh signifikan dan arahnya positif terhadap pertumbuhan ekonomi di Provinsi Jambi. Pengeluran pemerintah berpengaruh signifikan dan arahnya positif terhadap pertumbuhan ekonomi. Netekspor berpengaruh signifikan dan arahnya positif terhadap pertumbuhan ekonomi di Provinsi Jambi. Nilai produksi, kurs, pendapatan luar negeri dan 
pertumbuhan ekonomi berpengaruh signifikan terhadap net ekspor di Provinsi Jambi. Sementara itu, secara parsial nilai produksi berpengaruh signifikan dan positif terhadap net ekspor. Kurs berpengaruh signifikan dan arahnya negatif terhadap net ekspor di Provinsi Jambi. Pendapatan luar negeri berpengaruh tidak signifikan dan arahnya positif terhadap net ekspor di Provinsi Jambi. Pertumbuhan ekonomi berpengaruh signifikan dan positif terhadap net ekspor di Provinsi Jambi.

Adrian D dan Lubis (2012) meneliti dengan judul: Analisis Faktor Yang Mempengaruhi Kinerja Ekspor Indonesia, hasil penelitian menunjukkan Perkembangan kinerja ekspor Indonesia secara historis bersifat dinamik, yang dipengaruhi oleh perubahan kondisi ekonomi dunia yang sifatnya turbulen. Model proyeksi yang dihasilkan dalam penelitian ini merupakan modek proyeksi ekspor Indonesia dengan dunia dengan memperhatikan beberapa negara tujuan utama ekspor Indonesia, namun model yang disusun merupakan model linear dinamik dengan melihat sisi permintaan dan penawaran dari sektor pertanian dan industri.

Mega Febriyenti, Hasdi Aimon dan Zul Azhar (2013) meneliti dengan judul: Faktor Faktor Yang Mempengaruhi Cadangan Devisa Dan Net Ekspor Di Indonesia, hasil penelitian menunjukkan Netekspor, utang luar negeri, dan cadangan devisa periode sebelumnya mempengaruhi cadangan devisa di Indonesia secara signifikan. Dengan kata lain, terjadinya peningkatan terhadap net ekspor, utang luar negeri serta cadangan devisa periode sebelumnya akan berdampak terhadap peningkatan cadangan devisa. Sebaliknya, apabila net ekspor, utang luar negeri serta cadangan devisa periode sebelumnya mengalami penurunan maka cadangan devisa juga akan mengalami penurunan. Sedangkan variabel FDI tidak mempengaruhi cadangan devisa di Indonesia secara signifikan. Kenaikan atau penurunan tidak berdampak terhadap kenaikan atau penurunan cadangan devisa.

\section{Kerangka Pemikiran}

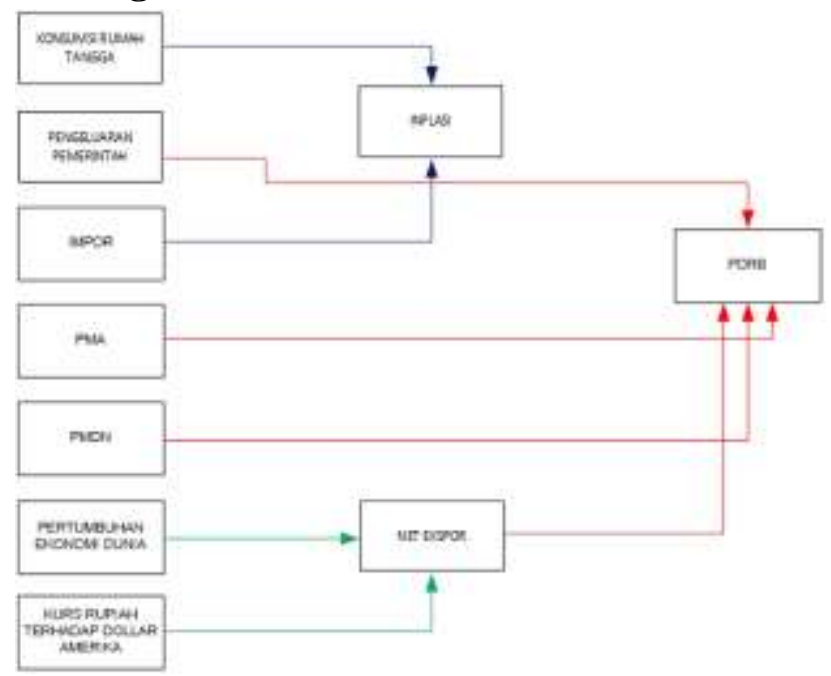

\section{Gambar 1. Kerangka Pemikiran}

Skema hubungan antara pertumbuhan ekonomi, Inflasi dan net ekspor dengan variabel-variabel yang mempengaruhinya dapat digambarkan sebagai berikut :

1. Model Produk Domestik Regional Bruto $Y=a+\beta 1 G_{i t}+\beta 2 P M A_{i t}+\beta 3 P M D N_{i t}$ $+\beta 4 N X_{i t}+\varepsilon_{i}$

Keterangan;

$\mathrm{Y} \quad=$ Produk Domestik Regional Bruto (PDRB).

$\mathrm{G}=$ Pengeluaran Pemerintah

PMA = Penanaman Modal Asing

PMDN $=$ Penanaman Modal Dalam Negeri

$\mathrm{NX}=$ Net Ekspor

$\mathrm{a}=$ konstanta

$\beta 1-\beta 4=$ koefisien

$\mathrm{i}=$ cross section

$\mathrm{t}=$ time series

$\varepsilon_{\mathrm{i}} \quad=$ errorterm

2. Model Inflasi

Inf $=a+\beta 1 R T_{i t}+\beta 2 M_{i t}+\varepsilon_{i}$ 
Keterangan;

$\begin{aligned} \text { Inf } & =\text { Inflasi } \\ \mathrm{RT} & =\text { Konsumsi Rumah Tangga } \\ \mathrm{M} & =\text { Impor } \\ \mathrm{a} & =\text { konstanta } \\ \beta 1-\beta 2 & =\text { koefisien } \\ \mathrm{i} & =\text { cross section } \\ \mathrm{t} & =\text { time series } \\ \varepsilon_{\mathrm{i}} & =\text { errorterm }\end{aligned}$

3. Model Net Ekspor

$N X=a+\beta 1 G D U N I A_{i t}+\beta 2 K D_{i t}+\varepsilon_{i}$

Keterangan;

$\begin{array}{lll}\text { NX } & = & \text { Net Ekspor } \\ \text { GDUNIA } & = & \text { Pertumbuhan } \\ \text { KD } & = & \text { Kurs Rupiah Terhadap } \\ & & \text { Dollar Amerika } \\ \mathrm{a} & = & \text { konstanta } \\ \beta 1-\beta 2= & \text { koefisien } \\ \mathrm{i}= & \text { cross section } \\ \mathrm{t}= & \text { time series } \\ \varepsilon_{\mathrm{i}}= & \text { errorterm }\end{array}$

\section{Hipotesis Penelitian}

Berdasarkan perumusan masalah, maka hipotesis penelitian ini adalah:

1. Model Regresi Produk Domestik Regional Bruto

a. Diduga Pengeluaran Pemerintah berpengaruh positif terhadap Produk Domestik Regional Bruto Provinsi di Indonesia.

b. Diduga Investasi (PMA dan PMDN) berpengaruh positif terhadap Produk Domestik Regional Bruto Provinsi di Indonesia.

c. Diduga Net ekspor berpengaruh positif terhadap Produk Domestik Regional Bruto Provinsi di Indonesia.

2. Model Regresi Inflasi

a. Diduga Konsumsi rumah tangga berpengaruh positif terhadap inflasi Provinsi di Indonesia b. Diduga Impor berpengaruh positif terhadap inflasi Provinsi di Indonesia

3. Model Regresi Net Ekspor

a. Diduga Pertumbuhan ekonomi dunia berpengaruh positif terhadap net ekspor Provinsi di Indonesia

b. Diduga Kurs Rupiah berpengaruh negatif terhadap net ekspor Provinsi di Indonesia.

\section{Metode Penelitian \\ Ruang Lingkup Penelitian}

Penelitian ini merupakan kajian tentang faktor - faktor yang mempengaruhi pertumbuhan ekonomi, inflasi dan net ekspor Provinsi di Indonesia dalam kurun waktu tahun 2009 sampai dengan tahun 2013. berupa data panel yaitu gabungan dari data bertipe cross-section dan Time Series. Meliputi data dari 33 provinsi di Indonesia. Adapun faktor - faktor yang mempengaruhi pertumbuhan pertumbuhan ekonomi Provinsi di Indonesia yang dianalisis adalah Pengeluaran Pemerintah, Nilai ekspor bersih dan Investasi Provinsi di Indonesia. Faktor faktor yang mempengaruhi inflasi Provinsi di Indonesia yang dianalisis adalah Pengeluaran pemerintah, konsumsi rumah tangga dan impor Provinsi di Indonesia. Sedangkan faktor yang mempengaruhi net ekspor Provinsi di Indonesia yang dianalisis adalah pertumbuhan ekonomi dunia dan kurs Rupiah terhadap Dollar Amerika Provinsi di Indonesia.

\section{Jenis dan Sumber Data}

Jenis data yang digunakan dalam penelitian ini adalah datasekunderyang diperoleh dari Badan Pusat Statistik (BPS), Bank Indonesia (BI), Badan Koordinasi Penanaman Modal (BKPM), Kementerian Perdagangan dan Bank Dunia serta sumber lain yang terkait dengan penelitian ini. 
Data yang digunakan adalah data sekunder selama periode tahun 2009 s/d 2013. Harga konstan dengan memakai tahun dasar 2000 digunakan sebagai dasar pengamatan dengan pertimbangan perkembangan angka-angka pendapatan regional dari tahun ke tahun semata-mata disebabkan olehperkembangan riil/nyata dan bukan dipengaruhi oleh perubahan harga, baik harga naik maupun turun (BPS, 2004). Pemutakhiran tahun dasar penghitungan PDRB dari tahun dasar 1993 ke tahun dasar 2000 menjadi perlu dilakukan agar hasil estimasi angka PDRB menjadi lebih realistis.

\section{Metode Pengumpulan Data}

Dalam penelitian ini data yang dikumpulkan adalah data sekunder yang berasal dari data instansi-instansi yang terkait yaitu misalnya Badan Pusat Statistik, Badan Koordinasi Penanaman Modal serta Kementerian Perdagangan.

\section{Defenisi Operasional}

Untuk mempermudah pemahaman terhadap istilah dari variable yang digunakan pada penelitian ini, maka berikut ini dijelaskan perihal batasan operasional sebagai berikut:

a. Produk Domestik Bruto adalah keseluruhan nilai tambah barang dan jasa oleh berbagai sektor ekonomi di suatu daerah dalam waktu tertentu (Rupiah/tahun). Data PDRB digunakan adalah PDRB Provinsi di Indonesia atas harga konstan tahun 2000. PDR Batas dasar harga konstan digunakan untuk menunjukkan laju pertumbuhan ekonomi secara keseluruhan dari tahun ketahun. PDRB harga konstan menunjukkan nilai tambah barang dan jasa yang dihitung menggunakan harga tahun 2000 sebagai tahun dasar. Data PDRB dikeluarkan oleh BPS dan dinyatakan dalam satuan rupiah. b. Pengeluaran Pemerintah yaitu belanja pemerintah atas barang dan jasa yang dilakukan pemerintah Provinsi di Indonesia dengan tujuan untuk memenuhi kebutuhan rutin dan pembangunan dihitung dalam rupiah.

c. Nilai ekspor yaitu nilai ekspor barang dan jasa Provinsi di Indonesia yang dihitung dalam rupiah.

d. Nilai Impor yaitu nilai ekspor barang dan jasa Provinsi di Indonesia yang dihitung dalam rupiah.

e. Nilai Net ekspor yaitu nilai nilai ekspor barang dan jasa dikurangi nilai impor barang dan jasa Provinsi di Indonesia yang dihitung dalam rupiah.

f. Konsumsi rumah tangga yaitu rata - rata pengeluaran rumah tangga perkapita sebulan atas barang dan jasaProvinsi di Indonesia yang dilakukan dihitung dalam rupiah.

g. Inflasi yaitu inflasi harga konsumenProvinsi di Indonesia yang dihitung dalam persentasi tahunan.

h. Pertumbuhan ekonomi Dunia yaitu tingkat pertumbuhan ekonomi di Dunia dalam persen.

i. Kurs Rupiah yaitu nilai mata uang rupiah terhadap dollar Amerika.

j. Realisasi nilai PMAadalah realisasi penanaman modal asing (PMA) Propinsi di Indonesia, dinyatakan dalam satuan Rupiah.

k. Realisasi nilai PMDNadalah realisasi penanaman modal dalam negeri (PMDN) Propinsi di Indonesia, dinyatakan dalam satuan Rupiah

\section{Teknik Analisis}

Teknik analisis ekonometrikyang digunakan dalam penelitian ini adalahmodel data panel. Datapanel merupakan kombinasi dari databertipecross-section dan Time Series (yakni sejumlah variabel diobservasi atas 
sejumlah kategori dan dikumpulkandalam suatu jangka waktu tertentu (Rosadi,2012:271).

Model-model estimasi dalam data panel ini tergantung pada asumsi-asumsi terhadap intersep, slopekoefisien, dan variabel gangguannya, error term. Beberapa kemungkinan asumsi adalah sebagai berikut:

1. Asumsi bahwa intersep dan slopekoefisien adalah konstan sepanjang waktu dan ruang serta variabel gangguan menangkap perbedaan antar waktu dan individual.

2. Slopekoefisien konstan dan intersep berbeda antara individu (fixed effectmodel).

3. Slopekoefisien konstan tetapi intersep bervariasi antar individu dan waktu.

4. Seluruh koefisien (intersep dan slopekoefisien) bervariasi antar individu.

5. Intersep dan slopekoefisien bervariasi antar individu dan waktu.

Untuk mengestimasi parameter model dengan data panel, terdapat beberapa teknik yang ditawarkan,yaitu:

1. Koefisien Tetap Antar Waktu danIndividu (Common Effect): Ordinary Least Square

Teknik ini tidak ubahnya dengan membuat regresi dengan data crosssection atau time series. Akan tetapi untuk data panel, sebelum membuat regresi harus menggabungkan data cross-section dengan data time series (pooldata). Kemudian data gabungan ini diperlakukan sebagai suatu kesatuan pengamatan untuk mengestimasi model dengan metode OLS. Metode ini dikenal dengan estimasi Common Effect. Akan tetapi dengan menggabungkan data maka tidak dapat melihat perbedaan baik antar individu maupun antar waktu. Atau dengan kata lain dalam pendekatan ini tidak memperhatikan dimensi individu maupun waktu. Diasumsikan bahwa perilaku data antar negara sama dalam berbagai kurun waktu.

\section{Model Efek Tetap (Fixed Effect)}

Pada pembahasan sebelumnya, mengasumsikan bahwa intersep maupun slope adalah sama baik antar waktu maupun antar negara. Namun, asumsi ini jelas sangat jauh dari kenyataan sebenarnya. Adanya variabel-variabel yang tidak semuanya masuk dalam persamaan model memungkinkan adanya intercept yang tidak konstan. Atau dengan kata lain, intercept ini mungkin berubah untuk setiap individu danwaktu. Pemikiran inilah yang menjadi dasar pemikiran pembentukan model tersebut.

\section{Model Efek Random (Random Effect)}

Bila pada Model Efek Tetap, perbedaan antar-individu dan atau waktu dicerminkan lewat intercept, maka pada Model Efek Random, perbedaant ersebut diakomodasi lewat error. Teknik ini juga memperhitungkan bahwa error mungkin berkorelasi sepanjang time series dan cross section.

Menurut, Nachrowi (2006, 318), pemilihan metode Fixed Effect atau metode Random Effect dapat dilakukan dengan pertimbangan tujuan analisis, atau ada pula kemungkinan data yang digunakan sebagai dasar pembuatan model, hanya dapat diolah oleh salah satu metode saja akibat berbagai persoalan teknis matematis yang melandasi perhitungan. Dalam software Eviews, metode Random Effect hanya dapat digunakan dalam kondisi jumlah individu bank lebih besar dibanding jumlah koefisien termasuk intersep. Selain itu, menurut beberapa ahli Ekonometri dikatakan bahwa, jika data panel yang dimiliki mempunyai jumlah waktu (t) lebih besar dibandingkan jumlah individu (i), maka disarankan menggunakan metode Fixed Effect. Sedangkan jika data panel yang dimiliki mempunyai jumlah waktu (t) lebih kecil 
dibandingkan jumlah individu (i), maka disarankan menggunakan metode Random Effect.

\section{a. Uji Statistik F (Uji Chow)}

Untuk mengetahui model mana yang lebih baik dalam pengujian data panel, bisa dilakukan dengan penambahan variabel dummy sehingga dapat diketahui bahwa intersepnya berbeda dapat diuji dengan uji Statistik F. Uji ini digunakan untuk mengetahui apakah teknik regresi data panel dengan metode Fixed Effect lebih baik dari regresi model data panel tanpa variabel dummy atau metode Common Effect.

Hipotesis pada uji ini adalah bahwa intersep sama, atau dengan kata lain model yang tepat untuk regresi data panel adalah Common Effect, dan hipotesis alternatifnya adalah intersep tidak sama atau model yang tepat untuk regresi data panel adalah Fixed Effect.

Nilai Statistik F hitung akan mengikuti distribusi statistik $F$ dengan derajat kebebasan (deggre of freedom) sebanyak $\mathrm{m}$ untuk numerator dan sebanyak $\mathrm{n}-\mathrm{k}$ untuk denumerator. $\mathrm{m}$ merupakan merupakan jumlah restriksi atau pembatasan di dalam model tanpa variabel dummy. Jumlah restriksi adalah jumlah individu dikurang satu. $\mathrm{n}$ merupakan jumlah observasi dan $\mathrm{k}$ merupakan jumlah parameter dalam model Fixed Effect. Jumlah observasi (n) adalah jumlah individu dikali dengan jumlah periode, sedangkan jumlah parameter dalam model Fixed Effect (k) adalah jumlah variabel ditambah jumlah individu. Apabila nilai $\mathrm{F}$ hitung lebih besar dari $\mathrm{F}$ kritis maka hipotesis nul ditolak yang artinya model yang tepat untuk regresi data panel adalah model Fixed Effect. Dan sebaliknya, apabila nilai $\mathrm{F}$ hitung lebih kecil dari $\mathrm{F}$ kritis maka hipotesis nul diterima yang artinya model yang tepat untuk regresi data panel adalah model Common Effect.
Hipotesis yang dibentuk dalam Chow test adalah sebagai berikut:

$\mathrm{H}_{0}$ : Model Common Effect

$\mathrm{H}_{1}$ : Model Fixed Effect

$\mathrm{H}_{0}$ ditolak jika $P$-value lebih kecil dari nilai a. Sebaliknya, $\mathrm{H}_{0}$ diterima jika $P$-value lebih besar dari nilai a. Nilai a yang digunakan sebesar 5\%.

\section{b. Uji Hausman}

Hausman telah mengembangkan suatu uji untuk memilih apakah metode Fixed Effect dan metode Random Effect lebih baik dari metode Common Effect. Uji Hausman ini didasarkan pada ide bahwa Least Squares Dummy Variables (LSDV) dalam metode metode Fixed Effect dan Generalized Least Squares (GLS) dalam metode Random Effect adalah efisien sedangkan Ordinary Least Squares (OLS) dalam metode Common Effect tidak efisien. Dilain pihak, alternatifnya adalah metode OLS efisien dan GLS tidak efisien. Karena itu, uji hipotesis nulnya adalah hasil estimasi keduanya tidak berbeda sehingga uji Hausman bisa dilakukan berdasarkan perbedaan estimasi tersebut.

Statistik uji Hausman mengikuti distribusi statistik Chi-Squares dengan derajat kebebasan (df) sebesar jumlah variabel bebas. Hipotesis nulnya adalah bahwa model yang tepat untuk regresi data panel adalah model Random Effect dan hipotesis alternatifnya adalah model yang tepat untuk regresi data panel adalah model Fixed Effect. Apabila nilai statistik Hausman lebih besar dari nilai kritis Chi-Squares maka hipotesis nul ditolak yang artinya model yang tepat untuk regresi data panel adalah model Fixed Effect. Dan sebaliknya, apabila nilai statistik Hausman lebih kecil dari nilai kritis Chi-Squares maka hipotesis nul diterima yang artinya model yang tepat untuk regresi data panel adalah model Random Effect. 
Hipotesis yang dibentuk dalam Hausman test adalah sebagai berikut:

\section{$\mathrm{H}_{0}$ : Model Random Effect}

$\mathrm{H}_{1}$ : Model Fixed Effect

$\mathrm{H}_{0}$ ditolak jika $P$-value lebih kecil dari nilai a. Sebaliknya, $\mathrm{H}_{0}$ diterima jika $P$-value lebih besar dari nilai a. Nilai a yang digunakan sebesar 5\%.

Setelah mendapatkan parameter estimasi, langkah selanjutnya adalah melakukan berbagai macam pengujian terhadap parameter estimasi tersebut serta pengujian terkait model mana yang terbaik, yang akan dipilih diantara menggunakan metode OLS (common), model Fixed Effect dan model Random Effect. Pengujian tersebut berupa pengujian ekonometrik dan statistik. Pengujian ekonometrik dimaksudkan untuk mengestimasi parameter regresi dengan menggunakan fixedeffect, Sedangkan pengujian statistikyaitu meliputi:

a. Pengujian Model dengan Asumsi Klasik

Pengujian model terhadap asumsi klasik diberlakukan pada persamaan struktural yang meliputi uji multikolineritas, heteroskedasitas danautokorelasi.

1. Uji Heteroskedasitas

Heteroskedasitas merupakan fenomena terjadinya perbedaan varianantarseri data.Heteroskedasitas muncul apabila nilai varian dari variabel tak bebas (Yi) meningkat sebagai meningkatnya varian dari variabel bebas (Xi), maka varian dari Yi adalah tidak sama. Gejala heteroskedasitas lebih sering dalam data crosssection dari pada time series. Selain itu juga sering muncul dalam analisis yang menggunakan data rata-rata. Untuk mendeteksi keberadaan heteroskedasitas digunakan metode grafik scatterplot, uji White, dimana apabila nilai probabilitas (pvalue) observasi $\mathrm{R}^{2}$ lebih besar dibandingkan tingkat resiko kesalahan yang diambil (digunakan $\alpha=5 \%$ ), maka residual digolongkan homoskedasitas.

Hipotesis yang dibentuk dalam uji Heterokedastisitas adalah sebagai berikut:

$\mathrm{H}_{0}$ : Tidak ada Heterokedastisitas

$\mathrm{H}_{1}$ : ada Heterokedastisitas

2. Uji Autokorelasi

Autokorelasi didefinisikan sebagai korelasi antara anggota serangkaian observasi yang diurutkan menurut waktu (seperti dalam data timeseries) atau ruang (seperti dalam data crosssection). Autokorelasi pada umumnya lebih sering terjadi pada data time series walaupun dapat juga terjadi pada data cross section. Dalam data time series observasi diurutkan menurut urutan waktu secara kronologis. Maka dari itu besar kemunginan akan terjadi interkorelasi antara observasi yang berurutan, khususnya kalau interval antara dua observasi sangat pendek. Untuk mendeteksi ada tidaknya autokorelasi dilakukan uji Lagrange Multiplier ( $L M$ test) dimana apabila probabilitas observasi $\mathrm{R}^{2}>\alpha(5 \%)$, maka bebas dari auto korelasi.

Hipotesis yang dibentuk dalam uji Autokorelasi adalah sebagai berikut:

$\mathrm{H}_{0}$ : Tidak ada autokorelasi

$\mathrm{H}_{1}$ : ada Autokorelasi

\section{b. GoodnessofFitSuatuModel}

Ketepatan fungsi regresi sampel dalam menaksir nilai aktual dapat diukur dari goodness of fit suatu model persamaan regresinya. Pengukuran goodness of fit tersebut dapat dilakukan melalui nilai statistik t, nilai statistik $F$ dan koefisien determinasi. Perhitungan statistik disebut signifikan secara statistik apabila nilai uji statistiknya berada dalam daerah kritis (daerah dimana $\mathrm{H} 0$ ditolak). Sebaliknya disebut tidak signifikan bila nilai uji 
statistiknya berada dalam daerah dimana $\mathrm{H} 0$ diterima.

1. Uji Signifikansi Parameter Individual (Uji Statistik t)

Uji $\mathrm{t}$ dilakukan untuk mengetahui apakah variabel independen secara individual mempengaruhi variabel dependen. Uji $t$ dilakukan dengan membandingkan nilai statistik dengan tabel. Dalam pengujian ini dilakukan dengan uji 2 sisi (two tailtest) dengan tingkat kepercayaan $95 \%$ atau $\alpha=5 \%$ dengan hipotesis $\mathrm{Ho}_{0}: \beta 0=\beta 1=\beta_{2}=0$ dan $\mathrm{Ha}: \beta 0 \neq \beta 1 \neq \beta 1 \neq 0$.

2. Uji Signifikansi Simultan (Uji Statistik F)

Uji F digunakan untuk menguji apakah secara statistik bahwa koefisien regresi dari variabel independen secara bersama-sama memberikan pengaruh yang bermakna dengan membandingkan nilai probabilitas (Fstatistik) dengan $\mathrm{F}$ tabel, dengan kententuan jika F- Statistik > F tabel maka Ho ditolak dan $\mathrm{Ha}$ diterima berarti variabel independen berpengaruh signifikan terhadap variabel dependen secara bersamasama, dengan formulasi hipotesis sebagai berikut:

Ho : $\beta 0=\beta=\beta_{2}=0$, variabel independen secara bersama-sama tidak berpengaruh terhadap variabel dependen. Ha : $\beta 0 \neq \beta 1 \neq \beta 2 \neq 0$, variabel independen secara bersama-sama berpengaruh terhadap variabel dependen.

3. Koefisien Determinasi

Koefisien determinasi $\left(\mathrm{R}^{2}\right)$ pada intinya mengukur seberapa jauh kemampuan model dalam menerangkan variasi variabel terikat (dependen). Nilai koefisien determinasi adalah antara nol dan satu. Nilai $\mathrm{R}^{2}$ yang kecil berarti kemampuan variabel-variabel independen dalam menjelaskan variasi variabel dependen amat terbatas. Nilai yang mendekati satu berarti variabelvariabel independen memberikan hampir semua informasi yang dibutuhkan untuk memprediksi variabel-variabel dependen.

Secara umum koefisien untuk data silang (crosssection) relatif lebih rendah karena adanya variasi yang besar antara masing-masing pengamatan, sedangkan data runtut waktu (time series) biasanya mempunyai nilai koefisien determinasi yang tinggi.

\section{Hasil dan Pembahasan}

Hasil Persamaan Regresi Produk Domestik Regional Bruto, Net Ekspor dan Inflasi

\section{Pengujian Hasil Persamaan Regresi Produk Domestik Regional Bruto}

Pengujian untuk mengetahui pengaruh realisasi Penanaman Modal Asing (PMA) Provinsi di Indonesia, realisasi Penanaman Modal Dalam Negeri (PMDN) Provinsi di Indonesia, Pengeluaran Pemerintah Provinsi di Indonesia dan Net Ekspor Provinsi di Indonesia terhadap Produk Domestik Regional Bruto Propinsi di Indonesia dilakukan dengan analisis regresi berganda. Dengan analisis regresi akan diketahui kekuatan dan arah hubungan antara variabel dependen yaitu Produk Domestik Regional Bruto Provinsi di Indonesia dengan variabel independen: realisasi nilai PMA Provinsi di Indonesia, PMDN Provinsi di Indonesia, pengeluaran pemerintah Provinsi di Indonesia dan Net Ekspor Provinsi di Indonesia. Teknik estimasi variabel dependen yang melandasi analis aregresi tersebut dinamakan Ordinary Least Square(OLS).

Dalam penentuan model terbaik antara 
common effect, fixed effect, dan random effect menggunakan dua teknik estimasi model. Dua teknik ini digunakan dalam regresi data panel untuk memperoleh model yang tepat dalam mengestimasi regresi data panel. Dua uji yang digunakan, pertama Chow test digunakan untuk memilih antara model common effect atau fixed effect. Kedua, Hausman test digunakan untuk memilih antara model fixed effect atau random effect yang terbaik dalam mengestimasi regresi data panel. Penggunaan kedua pengujian tersebut dalam pemilihan model terbaik regresi data panel ditunjukkan oleh gambar berikut:

\section{a. Uji Chow}

Berdasarkanpengujianfixedeffectdipero lehdatahasilpengujiansebagaiberikut:

Tabel 1.

Uji Chow (Likelihood Ratio) Produk Domestik Regional Bruto

\begin{tabular}{lrrr}
\hline Effects Test & Statisic & df & Prob. \\
\hline \hline Cross-section F & 370261111 & $-32,117$ & 0.000 \\
Cross-section Ch-square & 712.649904 & 32 & 0.000 \\
\hline
\end{tabular}

Sumber: Data sekunder yang diolah tahun 2009-2013

Berdasarkanhasildaripengujian uji chow, dapat dilihat bahwa cross-section $\mathrm{F}$ dan Cross-section Chi-square sebesar 0,000 atau lebih kecil dari 0,05. Dengan demikian berdasarkan hipotesis jika P-value $<0,05$ berarti $\mathrm{H}_{0}$ di tolak, maka metode yang digunakan adalah Fixed Effect Model.

\section{b. Uji Hausman}

Berdasarkan pengujian randomeffect diperoleh data hasil pengujian sebaga iberikut:

Tabel 2.

Uji Hausman (Hausman Test) Produk Domestik Regional Bruto

\begin{tabular}{lrrr}
\hline Test Simmary & Cir-Sq. Stutisic & Chi-Sq. d. & Prob. \\
\hline \hline Coss-section random & 178.690123 & 4 & 0.000 \\
\hline
\end{tabular}

Sumber: Data sekunder yang diolah tahun 2009-2013

Pada perhitungan yang telah dilakukan, dapat dilihat bahwa nilai probability pada uji Hausman memperlihatkan angka Crosssection random bernilai 0.0000 yang berarti lebih kecil dari 0,05. Dengan demikian berdasarkan hipotesis jika $\mathrm{P}$-value $<0,05$ berarti $\mathrm{H}_{0}$ di tolak, maka metode yang digunakan adalah Fixed Effect Model.

Berdasarkan hasil dari pengujian uji chow dan Hausman Test, maka metode pilihan yang digunakan dalam penelitian ini menggunakan Metode Fixed Effect.

Setelah melakukan pengujian atas metode yang akan digunakan maka selanjutnya perlu dilakukan pengujian asumsi klasik yang terdiri dari uji autokorelasi dan Uji Heterokedastisitas, berikut hasil dari uji asumsi klasik:

1. Uji Autokorelasi

Tabel 3.

Uji Autokorelasi Regresi Produk Domestik Regional Bruto

\begin{tabular}{llll} 
Breusch-Godfrey Serial Correlation LM Test & \\
\hline \hline F-statistic & 64.96507 & Prob. F(2,143) & 0.000 \\
Obs*R-squared & 71.40846 & Prob.Chi-Square(2) & 0.000 \\
\hline
\end{tabular}

Sumber: Data sekunder yang diolah tahun 2009-2013

Dari hasil tabel diatas dapat disimpulkan bahwa $\mathrm{H}_{0}$ ditolak, atau dapat dikatakan bahwa terdapat autokorelasi dalam model regresi.

\section{Uji Heterokedastisitas}

Tabel 4.

Uji Heterokedastisitas Regresi Produk Domestik Regional Bruto

\begin{tabular}{lrll} 
Heteroskedasticity Test: White & & \\
\hline \hline F-statistic & 0.55417 & Prob. F(4,145) & 0.6963 \\
Obs*R-squared & 2.2586 & Prob. Chi-Square(4) & 0.6883 \\
Scaled explaned SS & 7.32534 & Prob. Chi-Square(4) & 0.1197 \\
\hline
\end{tabular}


Sumber: Data sekunder yang diolah tahun 2009-2013

Dari hasil tabel diatas dapat disimpulkan bahwa $\mathrm{H}_{0}$ diterima, atau dapat dikatakan bahwa tidak terdapat Heterokedastisitas dalam model regresi.

Berdasarkan hasil uji asumsi klasik pada model regresi terdapat masalah autokorelasi. Pada model fixed effect, implikasi terjadi autokorelasi dan heterokedastisitas pada data panel dapat diperbaiki dengan berbagai macam cara, yaitu dengan merubah kebentuk model cross-section weights atau crosssection SUR. Berikut hasil model fixed effect setelah diperbaiki kebentuk model cross-section weights.

Tabel 5.

Uji Fixed Effect Produk Domestik Regional Bruto.

\begin{tabular}{|c|c|c|c|c|}
\hline Variable & Coefficient & Std. Error & t.Statistic & Prob. \\
\hline C & 4834491 & 1201262 & 40.24503 & 0,0000 \\
\hline o? & 0.003999 & 0.000159 & 25.18747 & 0.0000 \\
\hline PMA? & 3.477333 & 0.638586 & 5.445967 & 0.0000 \\
\hline PMDN? & 0.537725 & 0.10093 & 322127 & 0.0017 \\
\hline NET EKSPOR? & 0.00000415 & 0.00000091 & 4.564293 & 0.0000 \\
\hline \multicolumn{5}{|l|}{ Fised Erfeets (Creas) } \\
\hline JATLM:-C & $296,498.41$ & \multicolumn{2}{|l|}{ SULUT-C } & $10,125,32$ \\
\hline JABAR_C & $264,716.01$ & \multicolumn{2}{|l|}{ SULTENG-C } & $7,865.90$ \\
\hline JAKARTA-C & 260,04481 & \multicolumn{2}{|l|}{ NTB-C } & $7,494.42$ \\
\hline JATENO-C & $155,100,41$ & \multicolumn{2}{|l|}{ KALTENO-C } & $6,108.30$ \\
\hline SUMUT_-C & $97,048.08$ & \multicolumn{2}{|c|}{ JAMBL-C } & 6,05482 \\
\hline RLAU-C & 60.67450 & \multicolumn{2}{|c|}{ SULTENCGARALC } & $3,819.22$ \\
\hline BANTEN-C & $63,591,42$ & \multicolumn{2}{|c|}{ NTT-C } & $3,355.13$ \\
\hline KALILM-C & $61,311: 35$ & \multicolumn{2}{|c|}{ KEP_BABEL_C } & $2,896.85$ \\
\hline SUMSEEL $C$ & $49,328.12$ & \multicolumn{2}{|c|}{ PAPUA-C } & $1,059.19$ \\
\hline SUL SEL -.C & $35,610.21$ & \multicolumn{2}{|c|}{ BENGKULU-CC } & 608.06 \\
\hline KEP RIAU...C & $30,896.73$ & \multicolumn{2}{|c|}{ SULBAR-C } & $(904,14)$ \\
\hline SUMBAR-C & $27,258.37$ & \multicolumn{2}{|c|}{ GORONTALO-C } & $(2,937,22)$ \\
\hline I.AMCPUNG-C & $25,824,03$ & \multicolumn{2}{|c|}{ MAIUKU-C } & $(3,367.50)$ \\
\hline KALBAR_C & $17,300.58$ & \multicolumn{2}{|l|}{ MuLUT-C } & $(4,055.11)$ \\
\hline BALI C & $12,530.66$ & \multicolumn{2}{|l|}{$A C E H-C$} & $(8,408.52)$ \\
\hline KALSEL_CC & $12,364.72$ & \multicolumn{2}{|l|}{ PABAR-C } & $(19.647 .80)$ \\
\hline YOOYA-C & $11,536.65$ & & & \\
\hline R-squared & 0.998897 & \multicolumn{2}{|c|}{ Menen depersfeat var } & 100462.5 \\
\hline Adjusted R-squared & 0.995558 & \multicolumn{2}{|c|}{ 5.D. dependert vat } & $89586 \leqslant 2$ \\
\hline S.E of regrestion & 4390.745 & \multicolumn{2}{|c|}{ Sam sguared resid } & $2.26 \mathrm{E}+\infty$ \\
\hline F-statistic & 2944357 & \multirow{2}{*}{\multicolumn{2}{|c|}{ Durben-Watsen stat }} & 1.681997 \\
\hline Prob(F-statiatic) & 0,000 & & & \\
\hline
\end{tabular}

Sumber: Data sekunder yang diolah tahun 2009-2013

Berdasarkan estimasi yang dilakukan terhadap persamaan regresi, selanjutnya diperoleh persamaan regresi sebagai berikut:

$\begin{aligned} \text { PDRB = } & 48.344,91+0,003999 \\ & \text { Pengeluaran Pemerintah }+ \\ & 3,477333 \text { PMA }+0,537725\end{aligned}$

\section{PMDN + 0,00000415 Net Ekspor.}

1. Interpretasi dari persamaan regresi diatas adalah :

a) Koefisien $\beta_{1}=0,003999$

Koefisien variabel Pengeluaran Pemerintah Provinsi $\left(\beta_{1}\right)=0,003999$ dan bernilai positif yang menunjukkan bahwa Pengeluaran Pemerintah Provinsi berpengaruh positif terhadap PDRB. Jika Pengeluaran Pemerintah Provinsi naiksebesar $1 \%$ dan variabel yang lain tetap, maka PDRB akan naik sebesar 0,3999\%.

b) Koefisien $\beta_{2}=3,477333$

Koefisien variabel PMA Provinsi $\left(\beta_{2}\right)$ $=3,477333$ dan bernilai positifyang menunjukkan bahwa PMA Provinsi berpengaruh positif terhadap PDRB. Jika PMA Provinsi naik sebesar $1 \%$ dan variabel yang lain tetap, maka PDR Bakan naik sebesar 347,73\%.

c) Koefisien $\beta_{3}=0,537725$

Koefisien variabel PMDN Provinsi $\left(\beta_{3}\right)=0,537725$ dan bernilai positif yang menunjukkan bahwa PMDN Provinsi berpengaruh positif terhadap PDRB. Jika PMDN Provinsi naiksebesar $1 \%$ dan variabel yang lain tetap, maka PDRB akan naik sebesar 53,7725\%.

d) Koefisien $\beta_{4}=0,00000415$

Koefisien variabel Net Ekspor Provinsi $\left(\beta_{4}\right)=0,00000415$ dan bernilai positif yang menunjukkan bahwa Net Ekspor Provinsi berpengaruh positif terhadap PDRB. Jika Net Ekspor Provinsi naik sebesar $1 \%$ dan variabel yang lain tetap, maka PDRB akan naik sebesar Rp. $0,000415 \%$.

2. KoefisienDeterminasi 
Koefisien derminasi $\left(\mathrm{R}^{2}\right)$ merupakan kuadrat dari nilai korelasi majemuk yang dihasilkan dari persamaan regresi. Berdasarkan hasil perhitungan diperoleh nilai koefisien determinasi $\left(\mathrm{R}^{2}\right)=$ 0.998558. Halini menunjukkan bahwa besarnya variasi Produk Domestik Regional Bruto (PDRB) bisa diterangkan oleh variabel Pengeluaran Pemerintah Provinsi, Investasi PMA, investasi PMDN dan Net Ekspor sebesar 99,85\% dan sisanya sebesar $0,15 \%$ disebabkan oleh variabel lain diluar keempat variabel bebas tersebut.

3. Uji Signifikansi Parameter Individual (Uji Statistikt)

Pada uji statistik secara parsial dengan nilait kritis (critical value) pada $\mathrm{df}=(\mathrm{n}$ $\mathrm{k}$ ), dimana $\mathrm{n}$ adalah jumlah sampel dan $\mathrm{k}$ adalah jumlah variabel independen termasuk konstanta. Untuk menguji koefisian regresi parsial secara individu dari masing-masing variabel bebasakan diuji sebagai berikut:

a. Pengaruh Pengeluaran Pemerintah Provinsi di Indonesia terhadap Pertumbuhan Ekonomi Provinsi di Indonesia.

$H_{0}=\beta_{1}=0$ : Tidak terdapat pengaruh yang signifikan antara Pengeluaran Pemerintah terhadap Pertumbuhan Ekonomi.

$H_{1}=\beta_{1}>0$ : Terdapat pengaruh yang signifikan antara Pengeluaran Pemerintah terhadap Pertumbuhan Ekonomi.

Dari hasil regresi diperoleh nilai $\mathrm{t}$ hitung untuk Pengeluaran Pemerintah Provinsi di Indonesiasebesar25.18747 danpada ttabel dengan tingkat signifikansi sebesar $95 \%(\alpha=5 \%), \mathrm{df}=$
149 diperoleh 1,65514. Terlihat bahwa $\mathrm{t}$ hitung lebih besar dari $\mathrm{t}$ kritisatas, maka $\mathrm{H}_{0}$ ditolak yang berarti bahwa Pengeluaran Pemerintaah Provinsi di Indonesia berpengaruh secara signifikan terhadap pertumbuhan perekonomian propinsidi Indonesia.

Berdasarkan probabilitasnya, maka jika probabilitas lebih besar dari 0,05 maka $\mathrm{H}_{0}$ diterima dan jika probabilitas lebih kecil dari 0.05 maka $\mathrm{H}_{0}$ ditolak. Dari hasil perhitungan diketahui sig. atau significance adalah 0.000 atau probabilitas jauh dibawah 0,05, maka $\mathrm{H}_{0}$ ditolak artinya bahwa realisasi nilai Pengeluaran Pemerintah Provinsi di Indonesia benar - benar berpengaruh secara signifikan terhadap Pertumbuhan Ekonomi Propinsidi Indonesia sejak tahun 2009- 2013.

b. Pengaruh Investasi Penanaman Modal Asing (PMA) Provinsi di Indonesia terhadap Pertumbuhan Ekonomi Provinsi di Indonesia.

$H_{0}=\beta_{1}=0$ : Tidak terdapat pengaruh yang signifikan antara Investasi Penanaman Modal Asing (PMA) terhadap Pertumbuhan Ekonomi.

$H_{1}=\beta_{1}>0$ : Terdapat pengaruh yang signifikan antara Investasi Penanaman Modal Asing (PMA) terhadap Pertumbuhan Ekonomi.

Dari hasil regresi diperoleh nilai $\mathrm{t}$ hitung untuk Penanaman Modal Asing Provinsi di Indonesia sebesar 5.445367 dan pada $t$ tabel dengan tingkat signifikansi sebesar $95 \%$ 
$(\alpha=5 \%), \mathrm{df}=149$ diperoleh 1,65514 . Terlihat bahwa $\mathrm{t}$ hitung lebih besar dari t kritisatas, maka $\mathrm{H}_{0}$ ditolak yang berarti bahwa Penanaman Modal Asing Provinsi di Indonesia berpengaruh secara signifikan terhadap pertumbuhan perekonomian propinsidi Indonesia.

Berdasarkan probabilitasnya, maka jika probabilitas lebih besar dari $0,05 \mathrm{makaH}_{0}$ diterima dan jika probabilitas lebih kecil dari 0.05 maka $\mathrm{H}_{0}$ ditolak. Dari hasil perhitungan diketahui sig. atau significance adalah 0.000 atau probabilitas jauh dibawah 0,05, maka $\mathrm{H}_{0}$ ditolak artinya bahwa realisasi nilai Penanaman Modal Asing Provinsi di Indonesia benar - benar berpengaruh secara signifikan terhadap Pertumbuhan Ekonomi Propinsidi Indonesia sejak tahun2009-2013.

c. Pengaruh Investasi Penanaman Modal Dalam Negeri (PMDN) Provinsi di Indonesia terhadap Pertumbuhan Ekonomi Provinsi di Indonesia.

$$
\begin{aligned}
H_{0}=\beta_{1}=0: & \text { Tidak terdapat pengaruh } \\
& \text { yang signifikan antara } \\
& \text { Investasi Penanaman } \\
& \text { Modal Dalam Negeri } \\
& (\text { PMDN) terhadap } \\
& \text { Pertumbuhan Ekonomi. } \\
H_{1}=\beta_{1}>0: & \text { Terdapat pengaruh yang } \\
& \text { signifikan antara } \\
& \text { Investasi Penanaman } \\
& \text { Modal Dalam Negeri } \\
& (\text { PMDN) terhadap }
\end{aligned}
$$$$
\text { Pertumbuhan Ekonomi. }
$$

Dari hasil regresi diperoleh nilai $\mathrm{t}$ hitung untuk Penanaman Modal Dalam Negeri Provinsi di Indonesia sebesar 3.221270 dan pada $t$ tabel dengan tingkat signifikansi sebesar $95 \%(\alpha=5 \%), d f=$
149 diperoleh 1,65514. Terlihat bahwa t hitung lebih besar dari t kritisatas, maka $\mathrm{H}_{0}$ ditolak yang berarti bahwa Penanaman Modal Dalam Negeri Provinsi di Indonesia berpengaruh secara signifikan terhadap pertumbuhan perekonomian propinsi di Indonesia.

Berdasarkan probabilitasnya, maka jika probabilitas lebih besar dari 0,05 maka $\mathrm{H}_{0}$ diterima dan jika probabilitas lebih kecil dari 0.05 maka $\mathrm{H}_{0}$ ditolak. Dari hasil perhitungan diketahui sig. atau significance adalah 0.0017 atau probabilitas jauh dibawah 0,05 , maka $\mathrm{H}_{0}$ ditolak artinya bahwa realisasi nilai Penanaman Modal Dalam Negeri Provinsi di Indonesiabenar - benar berpengaruh secara signifikan terhadap Pertumbuhan Ekonomi Propinsi di Indonesia sejak tahun 2009-2013.

d. Pengaruh Investasi Net Ekspor Provinsi di Indonesia terhadap Pertumbuhan Ekonomi Provinsi di Indonesia.

$H_{0}=\beta_{1}=0$ : Tidak terdapat pengaruh yang signifikan antara Net Ekspor terhadap Pertumbuhan Ekonomi.

$H_{1}=\beta_{1}>0$ : Terdapat pengaruh yang signifikan antara Net Ekspor terhadap Pertumbuhan Ekonomi.

Dari hasil regresi diperoleh nilai $\mathrm{t}$ hitung untuk Net Ekspor Provinsi di Indonesia sebesar 4.564293 dan pada ttabel dengan tingkat signifikansi sebesar $95 \% \quad(\alpha=5 \%), \quad \mathrm{df}=149$ diperoleh 1,65514. Terlihat bahwa $\mathrm{t}$ hitung lebih besar dari t kritisatas, maka $\mathrm{H}_{0}$ ditolak yang berarti bahwa Net Ekspor Provinsi di Indonesia berpengaruh secara signifikan terhadap pertumbuhan perekonomian 
propinsi di Indonesia.

Berdasarkan probabilitasnya, maka jika probabilitas lebih besar dari 0,05 maka $\mathrm{H}_{0}$ diterima dan jika probabilitas lebih kecil dari 0.05 maka $\mathrm{H}_{0}$ ditolak. Dari hasil perhitungan diketahui sig. atau significance adalah 0.000 atau probabilitas jauh dibawah 0,05 , maka $\mathrm{H}_{0}$ ditolak artinya bahwa realisasi nilai Net Ekspor Provinsi di Indonesia benar - benar berpengaruh secara signifikan terhadap Pertumbuhan Ekonomi Propinsidi Indonesia sejak tahun 2009 - 2013.

4. Uji Signifikansi Parameter Simultan (Uji F)

Uji pengaruh simultan digunakan untuk mengetahui apakah variabel independen $t$ secara bersama-sama atau simultan mempengaruhi variabel dependent.

Uji Statistik secara serentak ditunjukkan oleh perbandingan nilai $\mathrm{F}$ hitung dengan $F$ tabel. Nilai $F$ tabel dengan $\mathrm{df}=(\mathrm{k}-1, \mathrm{n}-\mathrm{k})$, dengan derajat kepercayaan sebesar 95\% adalah sebesar 2,43 . Pada tabel output di atas terlihat bahwa pada persamaan, F hitung 2944.357 adalah jauh lebih besar dari pada $F$ tabelnya. Iniberarti bahwa keempat variabel independen signifikan dalam menjelaskan Pertumbuhan Ekonomi Propinsi di Indonesia.

\section{Pengujian Hasil Persamaan Regresi Net Ekspor}

Pengujian untuk mengetahui pengaruh nilai Kurs Rupiah terhadap Dollar Amerika dan Pertumbuhan Ekonomi Dunia terhadap Net Ekspor Propinsi di Indonesia dilakukan dengan analisis regresi berganda. Dengan analisis regresi akan diketahui kekuatan dan arah hubungan antara variabel dependen yaitu Net Ekspor Provinsi di Indonesia dengan variabel independen: Nilai Kurs Rupiah terhadap Dollar
Amerika dan Pertumbuhan Ekonomi Dunia. Teknik estimasi variabel dependen yang melandasi analisa regresi tersebut dinamakan Ordinary Least Square (OLS).

Dalam penentuan model terbaik antara common effect, fixed effect, dan random effect menggunakan dua teknik estimasi model. Dua teknik ini digunakan dalam regresi data panel untuk memperoleh model yang tepat dalam mengestimasi regresi data panel. Dua uji yang digunakan, pertama Chow test digunakan untuk memilih antara model common effect atau fixed effect. Kedua, Hausman test digunakan untuk memilih antara model fixed effect atau random effect yang terbaik dalam mengestimasi regresi data panel. Penggunaan kedua pengujian tersebut dalam pemilihan model terbaik regresi data panel ditunjukkan sebagai berikut:

\section{a. Uji Chow}

Tabel 6.

Uji Chow (Likelihood Ratio) Net Ekspor

\begin{tabular}{lcrr}
\hline Effects Test & Stabistic & df & \multicolumn{1}{c}{ Prob. } \\
\hline \hline Cross-sectionF & 40.855133 & -32.130 & 0.000 \\
Cross-sectionChi-suare & 396.50026 & 32 & 0.000 \\
\hline
\end{tabular}

Sumber: Data sekunder yang diolah tahun 2009-2013

Berdasarkan hasil dari pengujian uji chow, dapat dilihat bahwa cross-section $\mathrm{F}$ dan Cross-section Chi-square sebesar 0,000 atau lebih kecil dari 0,05. Dengan demikian berdasarkan hipotesis jika P-value $<0,05$ berarti $\mathrm{H}_{0}$ di tolak, maka metode yang digunakan adalah Fixed Effect Model.

\section{b. Uji Hausman}

Tabel 7.

Uji Huasman (Hausman Test) Net Ekspor

\begin{tabular}{lrrr}
\hline Test Surmary & Cir-Sg.Stantic Chisq. df & Prob. \\
\hline \hline Gross-sation random & 0.0000 & 2 & 1.000 \\
\hline
\end{tabular}

Sumber: Data sekunder yang diolah tahun 2009-2013 
Pada perhitungan yang telah dilakukan, dapat dilihat bahwa nilai probability pada uji Hausman memperlihatkan angka Crosssection random bernilai 1.0000 yang berarti lebih besar dari 0,05. Dengan demikian berdasarkan hipotesis jika $\mathrm{P}$-value > 0,05 berarti $\mathrm{H}_{0}$ di terima, maka metode yang digunakan adalah Fixed Effect Model.

Berdasarkan hasil dari pengujian uji chow dan Hausman Test, maka metode pilihan yang digunakan dalam penelitian ini menggunakan Metode Fixed Effect.

Setelah melakukan pengujian atas metode yang akan digunakan maka selanjutnya perlu dilakukan pengujian asumsi klasik yang terdiri dari uji autokorelasi dan Uji Heterokedastisitas, berikut hasil dari uji asumsi klasik:

1. Uji Autokorelasi

Tabel 8.

Breusd-jidAfútokcorelasi.Regresi Net Ekspor

\begin{tabular}{llll}
\hline \hline F-satistic & 208.0058 & Prob. F $(2,160)$ & 0.000 \\
Obs*R-squared & 119.1676 & Prob. Chi-Square(2) & 0.000 \\
\hline
\end{tabular}

Sumber: Data sekunder yang diolah tahun 2009-2013

2. Uji Heterokedastisitas

Tabel 9.

Uji Heterokedastisitas Regresi Net Ekspor Heteroskedasticity Test White

\begin{tabular}{llll}
\hline \hline F-statistic & 0.09172 & Prob. F $(2,162)$ & 0.9124 \\
Obs*R-squared & 0.18663 & Prob. Chi-Square(2) & 0.9109 \\
Scaled exphined SS & 1.28828 & Prob.Chi-Square(2) & 0.5251 \\
\hline
\end{tabular}

Sumber: Data sekunder yang diolah tahun 2009-2013

Dari hasil tabel diatas dapat disimpulkan bahwa $\mathrm{H}_{0}$ diterima, atau dapat dikatakan bahwa tidak terdapat Heterokedastisitas dalam model regresi.

Berdasarkan hasil uji asumsi klasik pada model regresi terdapat masalah autokorelasi. Pada model fixed effect, implikasi terjadi autokorelasi dan heterokedastisitas pada data panel dapat diperbaiki dengan berbagai macam cara, yaitu dengan merubah kebentuk model cross-section weights atau crosssection SUR. Berikut hasil model fixed effect setelah diperbaiki kebentuk model cross-section weights.

Tabel 10

Uji Model Fixed Effect Net Ekspor

\begin{tabular}{|c|c|c|c|c|}
\hline Variable & Coefficient & Std. Error & t-Statistic & Prob. \\
\hline 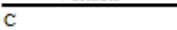 & $3.13 \mathrm{E}+09$ & $4.46 \mathrm{E}+08$ & 7.008607 & 0.0000 \\
\hline KURS? & -262435.3 & 40169.33 & -6.533226 & 0.0000 \\
\hline GWORLD? & 36323627 & 17056864 & 2.129561 & 0.0351 \\
\hline \multicolumn{5}{|l|}{ Fixed Effects (Cross) } \\
\hline KAL TIM--C & 23.530 .000 .000 & & MALUT--C & 3.031 .582 .143 \\
\hline RIAU--C & 17.130 .000 .000 & & KALTENG-C & 2961.000 .000 \\
\hline KEP RIAU-C & 16.430 .000 .000 & & SUL TENG-C & 2.828 .000 .000 \\
\hline KAL SEL--C & $8,110,000,000$ & & SULBAR--C & $2,720,000,000$ \\
\hline SUMUT-C & 7.730 .000 .000 & & BENGKULU--C & 2.667 .000 .000 \\
\hline SUMSEL--C & 5.700 .000 .000 & & PABAR-C & 2.620 .000 .000 \\
\hline PAPUA-C & 5350.000 .000 & & YOGYA-C & 2564.000 .000 \\
\hline KEP BABEL-CC & 4560.000 .000 & & GORONTALO-C & 2524.000 .000 \\
\hline JAMBI-C & $3,892,000,000$ & & NTT-C & $2,446,000,000$ \\
\hline SUMB AR-C & 3.888 .000 .000 & & MALUKU--C & 2.424 .000 .000 \\
\hline $\mathrm{ACEH}-\mathrm{C}$ & 3.703 .000 .000 & & BALI--C & 2224.000 .000 \\
\hline KALBAR-C & 3.400 .000 .000 & & JABAR--C & 1330.000 .000 \\
\hline NTB-C & $3,346,000,000$ & & JA ПIM--C & $(2,610,000,000)$ \\
\hline LAMPUNG-C & 3244.000 .000 & & JA TENG-C & $(4.780 .000 .000)$ \\
\hline SULTENGGARA--C & 3.171 .652 .139 & & BANTEN-C & $(5.680 .000 .000)$ \\
\hline SULSEL--C & 3.146 .254501 & & JAKARTA-C & $(33.370 .000 .000)$ \\
\hline SULUT-C & $3,085,943,637$ & & & \\
\hline R-squa red & 0.909707 & \multicolumn{2}{|c|}{ Mean dependent var } & $5.89 \mathrm{E}+08$ \\
\hline Adiusted R-s quared & 0.886092 & \multicolumn{2}{|c|}{ S.D. dependent var } & $8.91 \mathrm{E}+09$ \\
\hline S.E. of regression & $3.01 \mathrm{E}+09$ & \multicolumn{2}{|c|}{ Akaike info criterion } & 46.67152 \\
\hline Sum squared resid & $1.17 \mathrm{E}+21$ & \multicolumn{2}{|c|}{ Schwarz criterion } & 47.33036 \\
\hline Log tike thood & -3815.401 & \multirow{2}{*}{\multicolumn{2}{|c|}{ Hannan-Qvinn criter. }} & 46.93897 \\
\hline F-statistic & 38.52241 & \multirow{2}{*}{\multicolumn{2}{|c|}{ Durbin-Watson stat }} & 0.965491 \\
\hline Prob(F-statistic) & 0.00000 & & & \\
\hline
\end{tabular}

Sumber: Data sekunder yang diolah tahun 2009-2013

Berdasarkan estimasi yang dilakukan terhadap persamaan regresi, selanjutnya diperoleh persamaan regresi sebagai berikut:

Net Ekspor $=3.130 .000 .000-262.435,3$ KURS + 36.323.627 GWORLD.

1. Interpretasi dari persamaan regresi diatas adalah :

a. Koefisien $\beta_{1}=-262.435,3$

Koefisien variabel Kurs Rupiah Provinsi $\left(\beta_{1}\right)=-262.435,3$ dan bernilai negatif menunjukkan bahwa Kurs Rupiah Provinsi berpengaruh negatif terhadap Net Ekspor. Jika Kurs Rupiah Provinsi naik sebesar Rp. 1 dan variabel yang lain tetap, maka Net Eksporakan turun sebesar US\$262.435,3.

b. Koefisien $\beta_{2}=36.323 .627$

Koefisien variabel Pertumbuhan Ekonomi Dunia $\left(\beta_{2}\right)=36.323 .627$ dan bernilai positif yang menunjukkan bahwa Pertumbuhan Ekonomi Dunia berpengaruh positif 
terhadap Net Ekspor. Jika Pertumbuhan Ekonomi Dunia naiksebesar $1 \%$ dan variabel yang lain tetap, makaNet Ekspor Provinsi di Indonesia akan naik sebesar US\$. 36.323.627.

\section{Koefisien Determinasi}

Koefisien derminasi $\left(\mathrm{R}^{2}\right)$ merupakan kuadrat dari nilai korelasi majemuk yang dihasilkan dari persamaan regresi. Berdasarkan hasil perhitungan diperoleh nilai koefisien determinasi $\left(\mathrm{R}^{2}\right)=0.8860$. Halini menunjukkan bahwa besarnya variasi Net Ekspor Provinsi di Indonesia bisa diterangkan oleh variabel Kurs Rupiah terhadap Dollar Amerika dan Pertumbuhan Ekonomi Dunia sebesar $88,60 \%$ dan sisanya sebesar $11,40 \%$ disebabkan oleh variabel lain diluarkedua variabel bebas tersebut.

3. Uji Signifikansi Parameter Individual (Uji Statistikt)

Pada uji statistik secara parsial dengan nilai tkritis (critical value) pada $\mathrm{df}=(\mathrm{n}-$ $\mathrm{k}$ ), dimanan adalah jumlah sampel dan $\mathrm{k}$ adalah jumlah variabel independen termasuk konstanta. Untuk menguji koefisian regresi parsial secara individu dari masing-masing variabel bebasakan diuji sebagai berikut:

a. Pengaruh Kurs Rupiah terhadap Dollar Amerika Provinsi di Indonesia terhadap Net Ekspor Provinsi di Indonesia.

$$
\begin{aligned}
H_{0}=\beta_{1}=0: & \text { Tidak terdapat pengaruh } \\
& \text { yang signifikan antara } \\
& \text { Kurs Rupiah terhadap } \\
& \text { Dollar Amerika Provinsi } \\
& \text { di Indonesia terhadap Net } \\
& \text { Ekspor Provinsi di } \\
& \text { Indonesia. } \\
H_{1}=\beta_{1}>0: & \text { Terdapat pengaruh yang } \\
& \text { signifikan antara Kurs }
\end{aligned}
$$

Rupiah terhadap Dollar Amerika Provinsi di Indonesia terhadap Net Ekspor Provinsi di Indonesia.

Dari hasil regresi diperoleh nilai t hitung untuk Kurs Rupiah terhadap Dollar Amerika Provinsi di Indonesia sebesar -6.533226 dan pada $t$ tabel dengan tingkat signifikansi sebesar 95\% $(\alpha=5 \%), \quad \mathrm{df}=162$ diperoleh 1,65431. Terlihat bahwa $\mathrm{t}$ hitung lebih kecil dari t kritisatas, maka $\mathrm{H}_{0}$ ditolak yang berarti bahwa Kurs Rupiah terhadap Dollar Amerika Provinsi di Indonesia berpengaruh secara signifikan terhadap Net Ekspor propinsidi Indonesia.

Berdasarkan probabilitasnya, maka jika probabilitas lebih besar dari 0,05 maka $\mathrm{H}_{0}$ diterima dan jika probabilitas lebih kecil dari 0.05 maka $\mathrm{H}_{0}$ ditolak. Dari hasil perhitungan diketahui sig atau significance adalah 0.0000 atau probabilitas jauh di bawah 0,05, maka $\mathrm{H}_{0}$ ditolak artinya bahwa Kurs Rupiah terhadap Dollar Amerika Provinsi di Indonesia berpengaruh secara signifikan terhadap Net Ekspor Propinsi di Indonesia sejak tahun 2009- 2013.

b. Pengaruh Pertumbuhan Ekonomi Dunia terhadap Net Ekspor Provinsi di Indonesia.

$H_{0}=\beta_{1}=0$ : Tidak terdapat pengaruh yang signifikan antara Pertumbuhan Ekonomi Dunia terhadap Net Ekspor Provinsi di Indonesia.

$H_{1}=\beta_{1}>0$ : Terdapat pengaruh yang signifikan antara 


\section{Pertumbuhan Ekonomi \\ Dunia terhadap Net \\ Ekspor Provinsi di Indonesia.}

Dari hasil regresi diperoleh nilai $\mathrm{t}$ hitung untuk Pertumbuhan Ekonomi Duniasebesar2.129561 danpada ttabel dengan tingkat signifikansi sebesar $95 \%(\alpha=5 \%), \quad \mathrm{df}=162$ diperoleh 1,65431. Terlihat bahwa t hitung lebih besardari t kritisatas, maka $\mathrm{H}_{1}$ diterima yang berarti bahwa Petumbuhan Ekonomi Dunia berpengaruh secara signifikan terhadap Net Ekspor propinsi di Indonesia.

Berdasarkan probabilitasnya, maka jika probabilitas lebih besar dari 0,05 maka $\mathrm{H}_{0}$ ditolak dan jika probabilitas lebih kecil dari 0.05 maka $\mathrm{H}_{0}$ diterima. Dari hasil perhitungan diketahui sig. atau significance adalah 0.0351 atau probabilitas di bawah 0,05 , maka $\mathrm{H}_{0}$ ditolak artinya bahwa Pertumbuhan Ekonomi Dunia berpengaruh secara signifikan terhadap Net Ekspor Propinsi di Indonesia sejak tahun 2009-2013.

4. Uji Signifikansi Parameter Simultan (Uji F)

Uji pengaruh simultan digunakan untuk mengetahui apakah variabel independent secara bersama-sama atau simultan mempengaruhi variabel dependent.

Uji Statistik secara serentak ditunjukkan oleh perbandingan nilai $\mathrm{F}$ hitung dengan $\mathrm{F}$ tabel. Nilai $\mathrm{F}$ tabel dengan $\mathrm{df}=(\mathrm{k}-1, \mathrm{n}-\mathrm{k})$, dengan derajat kepercayaan sebesar $95 \%$ adalah sebesar 3,05. Pada tabel out put di atas terlihat bahwa pada persamaan, $\mathrm{F}$ hitung 38.52241 adalah jauh lebih besar dari pada $\mathrm{F}$ tabelnya. Ini berarti bahwa kedua variabel independen signifikan dalam menjelaskan Net Ekspor Propinsi di Indonesia.

\section{Pengujian Hasil Persamaan Regresi Inflasi}

Pengujian untuk mengetahui pengaruh rata-rata konsumsi perkapita sebulan Provinsi di Indonesia dan Impor Provinsi di Indonesia terhadap Inflasi Propinsi di Indonesia dilakukan dengan analisis regresi berganda. Dengan analisis regresi akan diketahui kekuatan dan arah hubungan antara variabel dependen yaitu Inflasi Provinsi di Indonesia dengan variabel independen : rata-rata konsumsi perkapita sebulan Provinsi di Indonesia dan Impor Provinsi di Indonesia. Teknik estimasi variabel dependen yang melandasi analisa regresi tersebut dinamakan Ordinary Leas tSquare (OLS).

Dalam penentuan model terbaik antara common effect, fixed effect, dan random effect menggunakan dua teknik estimasi model. Dua teknik ini digunakan dalam regresi data panel untuk memperoleh model yang tepat dalam mengestimasi regresi data panel. Dua uji yang digunakan, pertama Chow test digunakan untuk memilih antara model common effect atau fixed effect. Kedua, Hausman test digunakan untuk memilih antara model fixed effect atau random effect yang terbaik dalam mengestimasi regresi data panel. Penggunaan kedua pengujian tersebut dalam pemilihan model terbaik regresi data panel ditunjukkan sebagai berikut:

a. Uji Chow

Tabel 11.

Uji Chow (Likelihood Ratio) Inflasi

\begin{tabular}{lrrr}
\hline Effects Test & Statistic & df & Prob. \\
\hline \hline Cross-sectin F & 1.384132 & $-32,130$ & 0.1049 \\
Cross-sectin Chi-square & 48.377813 & 32 & 0.0317 \\
\hline
\end{tabular}

Sumber: Data sekunder yang diolah tahun 2009-2013

Berdasarkan hasil dari pengujian uji chow, dapat dilihat bahwa Cross-section Chi-square sebesar 0,0317 atau lebih kecil dari 0,05. Dengan demikian berdasarkan hipotesis jika $\mathrm{P}$-value $<0,05$ berarti $\mathrm{H}_{0}$ di 
tolak, maka metode yang digunakan adalah Fixed Effect Model.

\section{b. Uji Hausman}

Tabel 12.

Uji Hausman (Hausman Test) Inflasi

\begin{tabular}{|c|c|c|}
\hline TestSunay & Clisq.Sténsti & $\mathrm{Ctisqd}$ \\
\hline roscesobnrandan & 0.920621 & \\
\hline
\end{tabular}

Sumber: Data sekunder yang diolah tahun 2009-2013

Pada perhitungan yang telah dilakukan, dapat dilihat bahwa nilai probability pada uji Hausman memperlihatkan angka Crosssection random bernilai 0.6311 yang berarti lebih besar dari 0,05. Dengan demikian berdasarkan hipotesis jika $\mathrm{P}$-value > 0,05 berarti $\mathrm{H}_{0}$ di terima, maka metode yang digunakan adalah Fixed Effect Model.

Berdasarkan hasil dari pengujian uji chow dan Hausman Test, maka metode pilihan yang digunakan dalam penelitian ini menggunakan Metode Fixed Effect.

Setelah melakukan pengujian atas metode yang akan digunakan maka selanjutnya perlu dilakukan pengujian asumsi klasik yang terdiri dari uji autokorelasi dan Uji Heterokedastisitas, berikut hasil dari uji asumsi klasik:

\section{Uji Autokorelasi}

Tabel 13.

Uji Autokorelasi Regresi Inflasi Breusch-Godirey Serial Conrelation LM Test.

\begin{tabular}{llll}
\hline \hline F-statistic & 0.894579 & Prob. F(2,160) & 0.4108 \\
Obs*R-squared & 1.824665 & Prob. Chi-Square(2) & 0.4016 \\
\hline
\end{tabular}

Sumber: Data sekunder yang diolah tahun 2009-2013

Dari hasil tabel diatas dapat disimpulkan bahwa $\mathrm{H}_{0}$ diterima, atau dapat dikatakan bahwa tidak terdapat autokorelasi dalam model regresi.

\section{Uji Heterokedastisitas}

Tabel 14.

Uji Heterokedastisitas Regresi Inflasi
Heteroskedasticity Test: White

\begin{tabular}{lrll}
\hline \hline F-statistic & 0.2332 & Prob.F(2,162) & 0.7923 \\
Obs*R-squared & 0.47367 & Prob.Ch-Square(2) & 0.7891 \\
Scaled explained SS & 0.98408 & Prob.Ch-Square(2) & 0.6114 \\
\hline
\end{tabular}

Sumber: Data sekunder yang diolah tahun 2009-2013

Dari hasil tabel diatas dapat disimpulkan bahwa $\mathrm{H}_{0}$ diterima, atau dapat dikatakan bahwa tidak terdapat Heterokedastisitas dalam model regresi.

Berdasarkan hasil uji asumsi klasik pada model regresi tidak terdapat masalah autokorelasi dan heterokedastisitas. Berikut hasil model regresi Inflasi

Tabel 15.

Uji Fixed Effect Inflasi

\begin{tabular}{|c|c|c|c|c|}
\hline Variable & Coefficient & Std. Error & t-Staristic & Prob. \\
\hline $\begin{array}{l}\text { C } \\
\text { KONSUMSI? } \\
\text { IMPOR? }\end{array}$ & $\begin{array}{r}4.33891 \\
1.72 \mathrm{E}-06 \\
3.51 \mathrm{E}-12\end{array}$ & $\begin{array}{l}0.454366 \\
6.27 \mathrm{E}-07 \\
2.36 \mathrm{E}-11\end{array}$ & $\begin{array}{l}9.549382 \\
2.736078 \\
0.148557\end{array}$ & $\begin{array}{l}0.0000 \\
0.0071 \\
0.8821\end{array}$ \\
\hline \multicolumn{5}{|l|}{ Fixed Effects (Cross) } \\
\hline NTB--C & 6.12198 & & SUMUT--C & 4.42801 \\
\hline NTT--C & 5.85887 & & SULTENGGARA-C & 4.41073 \\
\hline KEP BABEL-CC & 5.50575 & & JATIM-C & 4.39219 \\
\hline KALBAR-C & 5.49384 & & BALI--C & 4.32337 \\
\hline LAMPUNG--C & 5.40424 & & JATENG--C & 4.30318 \\
\hline BENGKULU--C & 5.11312 & & YOGYA-C & 4.10969 \\
\hline KALTENG-C & 4.90842 & & SULSEL-C & 3.91922 \\
\hline MALUKU--C & 4.84692 & & RLAU--C & 3.65369 \\
\hline SUMRAR--C & 4.79937 & & MALUT--C & 3.64321 \\
\hline KALTIM-C & 4.64186 & & KEP RIAU--C & 3.47471 \\
\hline KALSEL--C & 4.63625 & & SUMSEL--C & 3.36260 \\
\hline SUL TENG--C & 4.63606 & & SULUT--C & 3.34611 \\
\hline JAMBI--C & 4.59505 & & JAB,AR--C & 3.12047 \\
\hline PABAR--C & 4.58742 & & PAPUA--C & 2.90866 \\
\hline GORONTALO-C & 4.52442 & & JAKARTA--C & 2.60394 \\
\hline BANTEN-C & 4.48277 & & ACEH-C & 2.56335 \\
\hline SULBAR--C & 4.46456 & & & \\
\hline R-squared & 0.494794 & Mean det & pendent var & 7.8108 \\
\hline Adjusted R-squared & 0.362663 & S.D. dep & pendert var & 4.440111 \\
\hline S.E. of regresion & 1.521509 & Sum sque & ared resid & 300.9485 \\
\hline F-statiscic & 3.744725 & Durbin-V & Watson star & 2.837268 \\
\hline Prob(F-statistic) & 0.000000 & & & \\
\hline
\end{tabular}

Sumber: Data sekunder yang diolah tahun 2009-2013

Berdasarkan estimasi yang dilakukan terhadap persamaan regresi, selanjutnya diperoleh persamaan regresi sebagai berikut:

Inflasi $=4,338910+0,00000172$ Konsumsi + 0,00000000000351 Impor.

1. Interpretasi dari persamaan regresi diatas 
adalah :

a. Koefisien $\beta_{1}=0,00000172$

Koefisien variabel rata - rata konsumsi perkapita sebulan Provinsi di Indonesia $\left(\beta_{1}\right)=0,00000172$ dan bernilai positif yang menunjukkan bahwa rata - rata konsumsi perkapita sebulan Provinsi di Indonesia berpengaruh positif terhadap Inflasi. Jika rata - rata konsumsi perkapita sebulan Provinsi di Indonesia naik sebesar Rp.1 dan variabel yang lain tetap, maka Inflasiakan naik sebesar $0,00000172 \%$.

b. Koefisien $\beta_{2}=0,0000000000351$

Koefisien variabel Impor Provinsi di Indonesia $\left(\beta_{2}\right)=0,0000000000351$ dan bernilai positif yang menunjukkan bahwa Impor Provinsi di Indonesia berpengaruh positif terhadap Inflasi Provinsi di Indonesia. Jika Impor Provinsi di Indonesia naik sebesar US\$. 1 dan variabelyanglain tetap, makaInflasi Provinsi di Indonesia akan naik sebesar 0,0000000000351\%.

\section{KoefisienDeterminasi}

Koefisien derminasi $\left(\mathrm{R}^{2}\right)$ merupakan kuadrat dari nilai korelasi majemuk yang dihasilkan dari persamaan regresi. Berdasarkan hasil perhitungan diperoleh nilai koefisien determinasi $\left(\mathrm{R}^{2}\right)=0.362663$. Hal ini menunjukkan bahwa besarnya variasi Inflasi Provinsi di Indonesia bisa diterangkan oleh variabel rata - rata konsumsi perkapita sebulan Provinsi di Indonesia dan Impor Provinsi di Indonesia sebesar 36,27\% dan selebihnya sebesar $63,73 \%$ disebabkan oleh variabel lain diluarkedua variabel bebas tersebut.

3. Uji Signifikansi Parameter Individual (Uji Statistik t)

Pada uji statistik secara parsial dengan nilai $\mathrm{t}$ kritis (critical value) pada $\mathrm{df}=(\mathrm{n}$ $\mathrm{k})$, dimana $\mathrm{n}$ adalah jumlah sampel dan $\mathrm{k}$ adalah jumlah variabel independen termasuk konstanta. Untuk menguji koefisian regresi parsial secara individu dari masing-masing variabel bebasakan diuji sebagai berikut:

a. Pengaruh rata - rata konsumsi perkapita sebulan Provinsi di Indonesia terhadap inflasi Provinsi di Indonesia.

$H_{0}=\beta_{1}=0$ : Tidak terdapat pengaruh yang signifikan antara rata - rata konsumsi perkapita sebulan Provinsi di Indonesia terhadap Inflasi Provinsi di Indonesia.

$H_{1}=\beta_{1}>0$ : Terdapat pengaruh yang signifikan antara rata rata konsumsi perkapita sebulan Provinsi di Indonesia terhadapInflasi Provinsi di Indonesia.

Dari hasil regresi diperoleh nilai $\mathrm{t}$ hitung untuk rata - rata konsumsi perkapita sebulan Provinsi di Indonesiasebesar2.736078 danpada ttabel dengan tingkat signifikansi sebesar $95 \% \quad(\alpha=5 \%), \quad d f=162$ diperoleh1, 65431. Terlihat bahwa $\mathrm{t}$ hitung lebih besar dari t kritisatas, maka $\mathrm{H}_{0}$ ditolak yang berarti bahwa rata - rata konsumsi perkapita sebulan Provinsi di Indonesia berpengaruh secara signifikan terhadap Inflasi provinsi di Indonesia.

Berdasarkan probabilitasnya, maka jika probabilitas lebih besar dari 0,05 maka $\mathrm{H}_{0}$ diterima dan jika probabilitas lebih kecil dari 0.05 maka $\mathrm{H}_{0}$ ditolak. Dari hasil perhitungan diketahui sig. atau 
significance adalah 0.0071 atau probabilitas jauh di bawah 0,05 , maka $\mathrm{H}_{0}$ ditolak artinya bahwa rata rata konsumsi perkapita sebulan Provinsi di Indonesia berpengaruh secara signifikan terhadap Inflasi Propinsidi Indonesia sejak tahun 2009- 2013.

b. Pengaruh Impor Provinsi di Indonesia terhadap Inflasi Provinsi di Indonesia. $H_{0}=\beta_{1}=0$ : Tidak terdapat pengaruh yang signifikan antara Impor Provinsi di Indonesia terhadap Inflasi Provinsi di Indonesia. $H_{1}=\beta_{1}>0:$ Terdapat pengaruh yang signifikan antara Impor Provinsi di Indonesia terhadap Inflasi Provinsi di Indonesia.

Dari hasil regresi diperoleh nilai t hitung untuk Impor Provinsi di Indonesia sebesar 0.148557 dan pada t tabel dengan tingkat signifikansi sebesar 95\% $(\alpha=5 \%)$, df $=162$ diperoleh 1,65431. Terlihat bahwa $\mathrm{t}$ hitung lebih kecil dari t kritis atas, maka $\mathrm{H}_{0}$ diterima yang berarti bahwa Impor Provinsi di Indonesia tidak berpengaruh secara signifikan terhadap Inflasi propinsi di Indonesia.

Berdasarkan probabilitasnya, maka jika probabilitas lebih besar dari 0,05 maka $\mathrm{H}_{0}$ diterima dan jika probabilitas lebih kecil dari 0.05 maka $\mathrm{H}_{0}$ ditolak. Dari hasil perhitungan diketahui sig. atau signi ficance adalah 0.8821 atau probabilitas jauh di atas 0,05 , maka $\mathrm{H}_{0}$ diterima artinya bahwa Impor Provinsi di Indonesia tidak berpengaruh secara signifikan terhadap Inflasi Propinsi di Indonesia sejak tahun 2009 - 2013.

4. Uji Signifikansi Parameter Simultan (Uji F)

Uji pengaruh simultan digunakan untuk mengetahui apakah variabel independent secara bersama-sama atau simultan mempengaruhi variabel dependent.

Uji Statistik secara serentak ditunjukkan oleh perbandingan nilai $\mathrm{F}$ hitung dengan $F$ tabel. Nilai $F$ tabel dengan $\mathrm{df}=(\mathrm{k}-1, \mathrm{n}-\mathrm{k})$, dengan derajat kepercayaan sebesar $95 \%$ adalah sebesar 3,05. Pada tabel out put di atas terlihat bahwa pada persamaan, F hitung 3.744725 adalahl ebih besar dari pada $F$ tabelnya. Iniberarti bahwa kedua variabel independen signifikan dalam menjelaskan Inflasi Propinsi di Indonesia.

\section{Kesimpulan dan Saran Kesimpulan}

Dari hasil penelitian mengenai Analisis Pertumbuhan Ekonomi, Inflasi dan Net Ekspor Provinsi di Indonesia dapat disimpulkan sebagai berikut:

1. Faktor - faktor yang mempengaruhi Pertumbuhan Ekonomi Provinsi di Indonesia selama tahun pengamatan 2009 - 2013 adalah Pengeluaran Pemerintah, PMA, PMDN dan Net Ekspor. Hasil Analisis mengenai pengaruh Pengeluaran Pemerintah, PMA, PMDN dan Net Ekspor terhadap Pertumbuhan Ekonomi Provinsi di Indonesia secara simultan menunjukkan hubungan yang positif signifikan. Secara parsial Pengeluaran Pemerintah Provinsi berpengaruh positif dan signifikan terhadap pertumbuhan ekonomi provinsi, dengan kata lain apabila ada peningkatan pengeluaran pemerintah provinsi maka pertumbuhan ekonomi provinsi juga akan mengalami peningkatan. PMA dan PMDN Provinsi 
berpengaruh positif signifikan terhadap pertumbuhan Ekonomi Provinsi, dengan kata lain apabila ada peningkatan PMA dan PMDN maka berpengaruh terhadap pertumbuhan ekonomi provinsi. Net Ekspor Provinsi berpengaruh positif signifikan terhadap pertumbuhan ekonomi, dengan kata lain apabila net ekspor provinsi meningkat maka berpengaruh terhadap peningkatan pertumbuhan ekonomi provinsi.

2. Faktor - faktor yang mempengaruhi Inflasi Provinsi di Indonesia selama tahun pengamatan 2009 - 2013 adalah rata rata konsumsi perkapita sebulan provinsi dan Impor provinsi. Hasil analisis secara simultan rata - rata konsumsi perkapita sebulan provinsi dan impor provinsi berpengaruh positif signifikan terhadap Inflasi Provinsi di Indonesia. Secara parsial rata - rata konsumsi perkapita sebulan provinsi berpengaruh positif signifikan terhadap Inflasi Provinsi di Indonesia atau dengan kata lain apabila ada peningkatan rata - rata konsumsi perkapita sebulan provinsi maka akan berpengaruh terhadap peningkatan Inflasi Provinsi di Indonesia. Impor Provinsi berpengaruh positif tetapi tidak signifikan terhadap Inflasi Provinsi di Indonesia atau dengan kata lain kenaikan impor Provinsi belum tentu akan menaikkan Inflasi Provinsi di Indonesia.

3. Faktor - faktor yang mempengaruhi Net Ekspor Provinsi di Indonesia selama tahun pengamatan 2009 - 2013 adalah Kurs Rupiah dan pertumbuhan ekonomi dunia. Secara simultan Kurs Rupiah dan Pertumbuhan Ekonomi Dunia berpengaruh positif signifikan terhadap net ekspor provinsi di Indonesia. Secara partial Kurs Rupiah berpengaruh negative signifikan terhadap net ekspor provinsi di Indonesia, atau dengan kata lain apabila
Kurs Rupiah terdepresiasi terhadap Mata Uang Dollar Amerika maka Net Ekspor Provinsi di Indonesia akan menurun. Pertumbuhan Ekonomi Dunia berpengaruh positif tidak signifikan terhadap Net Ekspor Provinsi di Indonesia, dengan kata lain apa bila ada peningkatan pertumbuhan ekonomi dunia belum tentu akan meningkatkan net ekspor provinsi di Indonesia.

\section{Saran}

Berdasarkan dari hasil penelitian dan pembahasan, beberapa upaya perlu dilakukan untuk meningkatkan Pertumbuhan Ekonomi, Net Ekspor dan pencapaian target Inflasi, antara lain:

1. Peranan PMA dan PMDN sesuai dengan semangat otonomi daerah harus dipacu dengan peningkatan situasi kondusif berinvestasi, pembuatan peta potensi daerah dan pembentukan unit pelayanan terpadu di daerah untuk mempermudah pelayanan pembuatan ijin usaha dan investasi.

2. Pemerintah Daerah Propinsi diharapkan mengalokasikan belanja daerah secara proporsional antara belanja rutin yang konsumtif dengan belanja pembangunan yang lebih memihak kepentingan publik sehingga mampu memberikan efek positif terhadap pertumbuhan ekonomi daerah.

3. Dengan terus meningkatnya daya beli atau konsumsi masyarakat atas barang dan jasa baik itu berupa pangan atau nonpangan maka perlu dilakukan peningkatan kualitas sumber daya pekerja, modernisasi teknologi produksi serta pembangunan industri manufaktur nasional agar kinerjanya meningkat sehingga dapat mengurangi kesenjangan output (output gap), memperlancar jalur distribusi barang nasional, supaya tidak terjadi kesenjangan penawaran dan permintaan di tingkat 
regional (daerah). Dalam jangka panjang pemerintah harus melakukan kajian dalam hal meningkatkan swasembada pangan dan pergantian musim, karena inflasi lebih dominan dipengaruhi oleh bahan pangan. Kebijakan impor hanya bersifat jangka pendek hanya untuk mencukupi kebutuhan yang telah mendesak.

4. Untuk meningkatkan net ekspor pemerintah harus menjaga stabilitas nilai tukar Rupiah dengan kebijakan mengintervensi pasar, mengurangi deficit neraca pembayaran dan menekan inflasi. Dengan kondisi ekonomi dunia yang sedang melemah kiranya perlu melakukan efisiensi biaya produksi, meningkatkan promosi produksi serta mencari pasar baru yang lebih potensial.

\section{DAFTAR PUSTAKA}

Arsyad, Lincoln. 1999. Ekonomi Pembangunan Edisi Kedua. STIE YKPN. Yogjakarta.

Badan Perencanaan Pembangunan Nasional (Bappenas), 2013, Pembangunan Daerah Dalam Angka 2013.

Badan Perencanaan Pembangunan Nasional (Bappenas), 2014, Pembangunan Daerah Dalam Angka 2014.

Badan Pusat Statistik, 2014. Produk Domestik Bruto Menurut Penggunaan 2008-2013.

Bank Indonesia. 2013. Laporan Perekonomian Indonesia 2013.

Boediono, 2001. Indonesia Menghadapi Ekonomi Global. BPFE Yogyakarta 2001.

Boediono, 2005. Teori Pertumbuhan Ekonomi. Yogyakarta: BPFE

Boediono. 1994. Teori Ekonomi Makro. Edisi Keempat. BPFE UGM. Yogyakarta.
Ernita, Dewi. Amar, Syamsul dan Sofyan, Efrizal. 2013. Analisis Pertumbuhan Ekonomi, Investasi dan Konsumsi di Indonesia. Jurnal Kajian Ekonomi, Januari 2013, Vol 1, No. 2.

Gilarso, T. 2007. Pengantar Ilmu Ekonomi Mikro. Edisi Revisi. Kanisius.

Goeltom, M dan M. Suardhani. 1997. Analisa Dampak Intervensi Bank Sentral Dalam Penerapan EksporImpor di Indonesia. Jurnal Ekonomi dan Keuangan Indonesia. Volume XIV No.1

Goeltom, M.S. (1998). Manajemen Nilai Tukar di Indonesia dan Permasalahannya. Jakarta: Bank Indonesia.

Gujarati, D. 2003. Ekonometrika Dasar. Zain, Sumarno [penerjemah]. Jakarta. Penerbit Erlangga.

Irawan dan Suparmoko, M. 1992. Ekonomika Pembangunan. BPFE Yogyakarta, 1992.

Jhingan, ML.2000. Ekonomi Pembangunan dan Perencanaan. PT. Raja Grafindo Persada, Jakarta.

Kementerian Perdagangan Republik Indonesia, 2013. Statistik Perdagangan Luar Negeri Indonesia. Direktorat Jenderal Pengembangan Ekspor Nasional (DJPEN), PEN/BSP/04/VI/2013.

Kuncoro, Mudrajad. 1997. Ekonomi Pembangunan: Teori, Masalah, dan Kebijakan. Edisi Pertama. UPP AMP YPKN. Yogyakarta.

Kuncoro, Mudrajat, 1997. Ekonomi Pembangunan: Teori, Masalah dan Kebijakan. UPP AMP YKPN Yogyakarta.

Mangkoesubroto, Guritno dan Algifari. 1998. Teori Ekonomi Makro. Yogyakarta: STIE YKPN. 
Mangkusoebroto, G. 1994. Ekonomi Publik. BPFE.Yogyakarta.

Mankiw, N. Gregory, 2007.Teori Makroekonomian, Edisi Keenam, Erlangga, Jakarta.

Mankiw, N. Gregory. 2000. Teori Makro Ekonomi. Edisi empat. Penerbit Erlangga. Jakarta.

Mishkin, N. Frederic. 2008. Ekonomi uang, Perbankan dan Pasar Keuangan. Edisi Kedelapan. Salemba empat

Nachrowi, D.N. dan H. Usman (2002). Penggunaan Teknik Ekonometrika. Jakarta: PT Raja Grafindo Persada.

Ragnar Nurkse. 2001. Trade and Development. Edited by Rainer Kattel, Jan A. Kregel and Erik S. Reinert. This edition first published in UK and USA 2001 by ANTHEM PRESS.

Rosadi, Dedi. 2012. Ekonometrika \& Runtut Waktu Terapan dengan EVviews: Aplikasi untuk Bidang Ekonomi, Bisnis dan Keuangan edisi kedua. Yogyakarta. Penerbit Andi.

Salvatore, D. 1997. Ekonomi Internasional. Edisikelima. Terjemahan. Erlangga, Jakarta.

Salvatore, D. 1997. International Economics, 11th Edition. John Wiley \& Sons.

Samuelson, PA dan Nordhaus, WD. 1997. Economics. The Mcgraw-hill Companis.

Sigit, Sujana. 2003. Kamus Besar Ekonomi. Pustaka Grafika.
Silva, Engla D. Wardi, Yunia dan Ainom, hasdi. 2013. Analisis Pertumbuhan Ekonomi, Investasi dan Inflasi di Indonesia. Jurnal Kajian Ekonomi, Januari 2013, Vol 1, No. 2.

Sukirno, Sadono. 2000. Makroekonomi Modern : Perkembangan Pemikiran dari Klasik hingga Keynesian Baru. PT. Raja Grafindo Pustaka. Jakarta.

Sukirno, Sadono. 2004. Pengantar Teori Makro Ekonomi. Raja Grafindo Persada. Jakarta.

Sukirno, Sadono. 2005. Makro Ekonomi Pengantar, Edisi Ketiga. Jakarta: PT Raja Grafindo Persada.

Sukirno, Sadono. 2005. Makroekonomi Modern. Perkembangan Pemikiran dari Klasik Hingga Keynesian Baru. Jakarta, Raja Grafindo Persada.

Sukirno, Sadono. 2010. Ekonomi Pembangunan: Proses, Masalah dan Dasar Kebijakan. Edisi Kedua. Kencana.

Suryana. 2000. Ekonomi Pembangunan : Problematika dan Pendekatan. Penerbit Salemba Empat Edisi Pertama, 2000.

Swaramarinda, Darma Rika dan Indriani, Susi. 2011. Pengaruh Pengeluaran Konsumsi dan Investasi Pemerintah Terhadap Pertumbuhan Ekonomi di Indonesia. Econosains, Volume IX, Nomor 2, Agustus 2011

Tambunan, Tulus. 2001. Perekonomian Indonesia: teori dan temuan empiris. Ghalia Indonesia. 
